\title{
Between Cologne and Oxford: Berthold of Moosburg and Thomas of York's Sapientiale
}

\author{
Fiorella Retucci \\ Universität zu Köln / Università del Salento
}

Berthold of Moosburg left us a monumental commentary on the Elements of Theology of Proclus, which represents a unique writing of medieval times. Berthold's commentary evolves into a philosophical odyssey, at the end of which the human being, solely with the aid of the natural light of the intellect (ductu luminis naturalis intellectus), ${ }^{2}$ reaches his final perfection and becomes not only blessed, but also god. Berthold realized his project concerning the divinization of the human being by drafting a summa, a broad encyclopedia of ancient and modern Platonism, thanks to which the metaphysical and impersonal principles to which Proclus had reduced the Homeric gods acquire a new, all-human face.

Little is known about Berthold's biography, but there is enough to place him and his activity in a precise historical and cultural context: Berthold was an active member of the German Dominican order and he succeeded Eckhart as the head of the Dominican general studium in Cologne; he was, in short, part of the circle of thinkers who continued the philosophical tradition that was initiated, in Cologne, by Albert the Great.

1 This paper is a reworked version of a paper published in 2019 under the title "Magister Thomas Anglicus Minor. Tommaso di York fonte dell'Expositio di Bertoldo di Moosburg," in Tra antichità e modernità. Studi di storia della filosofia medievale e rinascimentale, Quaderni di Noctua 5(2019), p. 1-41. The Appendix has been particularly revised and considerably increased, especially thanks to the valuable suggestions of Dr. Evan King, whom I would like to thank very much here. I am also grateful to Giovanni Lasorella, who studied the relationship between Thomas and Berthold as part of his master's thesis.

2 Berthold of Moosburg, Expositio super Elementationem theologicam Procli. Prologus. Propositiones 1-13, eds M.R. Pagnoni-Sturlese, L. Sturlese (Hamburg: Meiner, 1984), Exp. tit. A, p. $38,1.33$. 
The preservation of the philosophical heritage of the so-called Deutsche Dominikaner Schule 3 and the continuity of the Platonic tradition are both distinctive features that Berthold almost flaunts in the course of his work. It is therefore not a coincidence that he opens his work with a detailed Tabula auctoritatum and declares that his Expositio is actually a compilation made on the basis of two distinct groups of authors: the doctores ecclesiae, on the one hand, and the philosophifamosi, on the other. ${ }^{4}$

The list of the doctores ecclesiae begins with Dionysius the pseudoAreopagite, Augustine, Boethius, Eustratius of Nicaea, John Scotus Eriugena, and Calcidius, and ends with six authors chronologically closer to Berthold. The first of these six names is that of Thomas Aquinas. Thomas is followed by - in order - Albert the Great, who founded the Dominican studium generale of Cologne in 1248, Dietrich of Freiberg, a German Dominican active in Cologne in the second half of the thirteenth century, and Ulrich of Strassburg, a Dominican also linked to the studium of the preachers at Cologne. These are all more or less well-known thinkers studied by specialists in medieval philosophy. And they are, above all, Dominican authors, all in some way linked to the studium generale of Cologne.

The penultimate name on the list is that of a Frater Arnoldus Luscus. Berthold provides some further details about him in the course of his work: Arnold is a Dominican (ordinis Praedicatorum) who composed a treatise De periodis motuum et mobilium caelestium; he was a diligent observer and calculator of the movement of celestial bodies and author of a sophisticated table on the motion of the stars, which Berthold attached to and with which he

3 Cf. M. Grabmann, "Der Einfluss Alberts des Grossen auf das mittelalterliche Geistesleben," in Mittelalterliches Geistesleben, vol. 2 (München:Max HueberVerlag, 1936), p.325-412; G.M. Löhr, Die Kölner Dominikanerschule vom 14 bis zum 16. Jarhundert (Freiburg / Schweiz: Verl. der Paulusdr., 1946), p. 29-42; L. Sturlese, "Albert der Grosse und die deutsche philosophische Kultur des Mittelalters," in Freiburger Zeitschrift für Philosophie und Theologie 28(1981), p. 133147 (reprinted in: L. Sturlese, Homo divinus. Philosophische Projekte in Deutschland zwischen Meister Eckhart und Heinrich Seuse [Stuttgart: Kohlhammer, 2007], p. 1-13); N. Largier, "Die deutsche Dominikanerschule. Zur Problematik eines historiographiscen Konzepts," in J.A. Aertsen, A. Speer (eds), Geistesleben im 13. Jahrhundert (Berlin / New York: De Gruyter, 2000), p. 202-213; J.A. Aersten, Medieval Philosophy as Transcendental Thought. From Philip the Chancellor (ca. 1225) to Francisco Súarez (Leiden: Brill, 2012), p. 315-316; H. Anzulewicz, "Albertus Magnus und seine Schüler. Versuch einer Verhältnisbestimmung," in A. Speer, Th. Jeschke (eds), Schüler und Meister (Berlin / Boston: De Gruyter, 2016), p. 159-203, esp. p. $176-177$.

4 Berthold of Moosburg, Expositio super Elementationem theologicam Procli. Prologus. Propositiones 1-13, p. 3-4. 
concluded his commentary on Proposition 198 of the Elementatio theologica. ${ }^{5}$ The historical identity of Brother Arnold is still unknown. Isabelle Draelants suggested that he should be identified with Arnold of Saxony, a Dominican active in Cologne, Erfurt, and Paris in the thirteenth century and author of a well-known medieval encyclopedia entitled De floribus rerum naturalium, preserved in a single manuscript of the Amplonian collection in Erfurt. Further, a work of astrological content, transmitted anonymously in a manuscript preserved in Basel (Universitätsbibliothek, O.vi.4), is also attributed to Arnold of Saxony. ${ }^{6}$ Thus, if the identity of Frater Arnoldus was confirmed accordingly, he would also be a German Dominican linked to the studium generale of Cologne, where Berthold of Moosburg was active as lector generalis.

It is therefore not without reason that scholarly interest has been focused on these two aspects of Berthold's commentary: the reception of the Neoplatonic heritage and the continuity of the philosophical tradition of Albert the Great.

The last name on the list of doctores ecclesiae had not been identified with any historical figure for a long time. Berthold does not provide any further information about him, but provides only a rather generic name. Thus, the editors of the text have mostly hesitated to give a face and an identity to the Magister Thomas Anglicus Minor, who is the last authority expressly mentioned by Berthold in the Tabula auctoritatum.

Only in 1997, Françoise Hudry found some parallel passages in Berthold's text and the incomplete commentary on the Liber XXIV philosophorum by the English Franciscan Thomas of York. ${ }^{7}$ However, after a careful analysis, carried out in the context of more recent studies within the editorial project on the Sapientiale, ${ }^{8}$ Berthold's dependence on Thomas of York proved to be much stronger and more consequential than Hudry had indicated at the beginning.

The identification of the Sapientiale as a very important source of the Expositio added an important volume to Berthold's library. An interpretative

5 Berthold of Moosburg, Expositio super Elementationem theologicam Procli. Propositiones 184211, ed. L. Sturlese (Hamburg: Meiner, 2014), 198F, p. 147-148, l. 151-182.

6 I. Draelants, "La transmission du De animalibus d'Aristote dans le De floribus rerum naturalium d'Arnoldus Saxo," in C. Steel, G. Guldentops, P. Beullens (eds), Aristotle's Animals in the Middle Ages and Renaissance (Leuven: Leuven University Press, 1999), p. 126-158, at p. 131-132.

7 Liber viginti quattuor philosophorum, ed. F. Hudry (Turnhout: Brepols, 1997).

8 Cf. especially F. Retucci, "Magister Thomas Anglicus Minor. Eine neue Quelle der Expositio super Elementationem theologicam Procli Bertholds von Moosburg - das ungedruckte Sapientiale des Franziskaners Thomas von York," in Berthold of Moosburg, Expositio super Elementationem theologicam Procli. Prop. 136-159, ed. F. Retucci (Hamburg: Meiner, 2007), p. XXIII-XXXIX. 
evaluation of Berthold's reliance on Thomas of York, however, has not yet been attempted. There are four good reasons for this: first, Berthold's commentary on Proclus is a monumental work, and Thomas of York's work is even longer and more complex; second, Berthold only tacitly copies large excerpts from the Sapientiale, without even indicating that he is quoting from another text; third - and this is highly important -, the text of the Sapientiale is still almost entirely unpublished and studies devoted to the work of the English Franciscan are very rare.

Finally, Thomas' work was evaluated almost unanimously by scholars: the Sapientiale fits perfectly within the Franciscan tradition, and shows very few points of contact with the German Dominican one. This influential historiographical idea was introduced by Martin Grabmann, an eminent expert of the German Dominican school. According to him, the great historical significance of the Sapientiale is due to the fact that it was elaborated not by a Peripatetic but by an authentic Augustinian. ${ }^{9}$ Longpré was more or less of the same opinion, so much so that he defined the philosophical system of Thomas of York as a form of "Augustinisme authentique."10

In an article with a rather unequivocal title ("Great Fighters against Averroism"), published in 1930, Cristoforo Krzanic speaks of Thomas' explicit anti-Averroistic and anti-philosophical attitude:

Quando Tommaso di York si accinse a sintetizzare il sapere filosofico del mondo antico nella cornice delle idee evangeliche, dovette decidersi: assorbire o l'aristotelismo ellenico e arabico razionaleggiante, o il neoplatonismo nel tradizionalismo di Sant'Agostino, di Anselmo, di San Bernardo e dei Vittorini, che fino al secolo XIII avevano impresso le loro idee su tutte le questioni. [...] Tommaso di York per il primo - e lo seguirono tutti i maestri francescani - scelse, assorbì la filosofia tradizionale per non toccare la santità dei dommi con l'accettare l'aristotelismo. Tommaso fu francescano e non poteva scegliere diversamente, non poteva preferire Aristotele ad Agostino. [...] Ė sempre la teologia che fa capolino in ogni affermazione del pensiero francescano. ${ }^{11}$

M. Grabmann, "Die Metaphysik des Thomas von York," in Studien zur Geschichte der Philosophie. Festgabe zum 6o. Geburtstag Clemens Baeumker (Münster i.W.: Aschendorff, 1913), p. 181-193, at p. 191-192.

10 E. Longpré, "Fr. Thomas d'York, O.F.M. La première somme métaphysique du XIIIe siècle," in Archivum Franciscanum Historicum 19(1926), p. 875-930, at p. 893.

11 C. Krzanic, "Grandi lottatori contro l'Averroismo," in Rivista di filosofia neoscolastica 22(1930), p. 161-207, at p. 167-168. 
Giulio Bonafede, in his Il pensiero francescano (published in 1952), was convinced that there is no difference between Bonaventure's philosophical system and that of Thomas of York. Thus, Bonafede preferred to describe Thomas' arguments by quoting Saint Bonaventure, who, in his opinion, provided clearer expositions than his English confrère. ${ }^{12}$

Edgar Scully also concluded that

for Thomas of York the Augustinian tradition, after Sacred Scripture itself, is, and remains, the very embodiment of Christian wisdom to such a degree that Aristotle, or any other philosopher, could not essentially alter the time-honoured doctrines of Augustine, Boethius and Anselm.13

As Scully also maintained, the doctrinal content of the Sapientiale was nothing more than a re-presentation of the Augustinianism that was prevalent at the time. ${ }^{14}$

According to the scholarly literature, Thomas of York, a radical Augustinian, was, together with Bonaventure and Alexander of Hales, the founder of a uniform Franciscan tradition that was later inherited by William de la Mare, John Peckam, Peter John Olivi, Peter of Trabibus, and Richard of Middleton..$^{15}$ It was thus a tradition far away from the "deutscher Sonderweg" meticulously reconstructed by Loris Sturlese in his history of German medieval philosophy. ${ }^{16}$

More than a century after its publication was first announced, the text of the Sapientiale is only recently starting to become available in a modern edition of an international editorial project: the third book has just been published; ${ }^{17}$ the first is in print. Some observations about this text and the history of its

\footnotetext{
12 G. Bonafede, Il pensiero francescano nel secolo XIII (Palermo: Mori e Figli, 1952), p. 187-189.

13 E. Scully, "Thomas of York and his Use of Aristotle. An Early Moment in the History of British Philosophy," in Culture 2o(1959), p. 420-436, at p. 422-423. Scully, however, also acknowledged Thomas' philosophical attitude: "His display of worldly wisdom is, on the one hand, a continuation of the spirit of Grosseteste, who was engaged in the work of translating and commenting on Aristotle, and whose study of Arabic treatises in optics helped to engender and promote his metaphysics of light, all in support of Divinely revealed truth. On the other hand, it is in marked contrast to the attitude of some of his Franciscan successors on the continent, who, like John Peter Olivy, tend to disparage the role of philosophy in the conduct of Christian thought."

14 Scully, "Thomas of York," p. 436.

15 Krzanic, "Grandi lottatori," p. 164.

16 L. Sturlese, Die deutsche Philosophie im Mittelalter. Von Bonifatius bis zu Albert dem Großen (784-128o) (München: Beck, 1993), p. 388.

17 Cf. Thomas of York, Sapientiale. Liber III. Cap. 1-20, ed. A. Punzi (Firenze: SISME L-Edizioni del Galluzzo, 2020).
} 
reception in the work of the Dominican from Moosburg can therefore begin to be made on the basis of textual evidence.

The aim of this study is to provide an initial tool for analyzing the relationship between the German Dominican and the English Franciscan, while being aware that the list of citations in the Appendix is only a starting point for future research. I hope that the laborious work of philology may encourage the work of the history of philosophy to answer some questions that still remain. Why does Berthold of Moosburg, a Dominican from the Teutonian Province who grew up at the school of Albert the Great in Cologne, constantly and literally refer to the work of Thomas of York, an English Franciscan active in Oxford in the mid-13th century? What makes the Sapientiale so interesting in the eyes of the Dominican of Moosburg?

In my opinion, the Sapientiale and the Expositio converge on two points: first, the attempt to recover the classical and ancient heritage, aimed at founding self-sufficient philosophical wisdom and, second, the emphasis on the continuity of the Platonic tradition.

\section{The Revival of the Philosophical Heritage}

Written between 1250 and 126o, the Sapientiale is a complete treatise on metaphysics, which Martin Grabmann had already recognized in 1913 as "die einzige große Darstellung des Systems der Metaphysik ausder Ära derHochscholastik”.18

The work is composed of three parts of different length. The subjects of the individual parts are theology, ontology, and a special part of metaphysics concerning the world and the soul. Thomas never explicitly uses the expressions metaphysica generalis and metaphysica specialis to define the internal division of his metaphysics, even though a division conveniently signified by these terms is evident in the work.

Thomas constructs his "incomparable monument du savoir philosophique au XIII ${ }^{\mathrm{e}}$ siècle"19 by collecting a massive number of theological and philosophical sources, elaborating a true synthesis of Greek-Arab wisdom and Christian wisdom. His familiarity with classical authors prefigures the Oxonian medieval attitude towards antiquity, which characterized the so-called "classicizing group" of friars presented in the pioneering, well-documented study English Friars and Antiquity in the Early Fourteenth Century, published in 196o by Beryl

18 Grabmann, “Die Metaphysik," p. 191.

19 Longpré, “Fr. Thomas d'York," p. 891. 
Smalley. ${ }^{20}$ In the Sapientiale, Apuleius, Hermes, Cicero, Pliny the Elder, Seneca Rhetor, Lucius Annaeus Seneca, Valerius Maximus, and Macrobius - all called sapientes mundi - join Arabic, Jewish, and Patristic authors - called sapientes $D e i$ - in a clear attempt to synthesize Christian and philosophical wisdom.

An unpublished study by Virginia Brown ${ }^{21}$ allows us to quantify the use that Thomas made of the Latin classics in composing his work. In the Sapientiale, Cicero is mentioned by name 356 times. Although most of the quotations concern Ciceronian works that were well-known in the Middle Ages, Thomas of York also shows that he was familiar with minor works (he quotes De divinatione 28 times and the Paradoxa 17 times). Of the 315 mentions of Seneca, 275 quotations are explicitly derived from the Epistulae.

Now, with very rare exceptions, all quotations from the Latin classics reach Berthold's Expositio only through the Sapientiale by Thomas of York, as the analysis of parallel passages in the Sapientiale and the Expositio has shown.

Besides the Latin classics, the Sapientiale is deeply influenced by other sources, which we may divide into three distinct groups: Greek philosophers, called sapientes mundi; Fathers and medieval Latin authors, called sapientes Dei; Arabic and Jewish sources, also defined by Thomas as sapientes mundi. ${ }^{22}$

The philosophical sources of the Sapientiale by no means have a merely decorative function. This is already evident from the number of times they appear in the work. The investigation of the explicit sources of the entire first book is quite significant: in the first book, which deals with the existence, nature, and properties of God, the relation between the sapientes mundi and the sapientes Dei is clearly uneven. The sapientes mundi, among whom Thomas includes Aristotle, Plato, Averroes, Avicenna, Hermes, Avicebron, Maimonides, and Algazel are mentioned by name 1267 times. The sapientes Dei, represented above all by Augustine, Boethius, Dionysius the Areopagite, Gregory the Great, Anselm, John Damascene, and Bernard of Clairvaux, are mentioned explicitly only 397 times. ${ }^{23}$

20 B. Smalley, English Friars and Antiquity in the Early Fourteenth Century (Oxford: Blackwell, 196o), esp. p. $45^{-6}$.

21 V. Brown, "Latin Classical authors in the Sapientiale of Thomas of York." The study, kindly made available by Prof. James Hankins, is now preserved in the archival material collected in the Archivum fratris Thomae Eboracensis at the Thomas-Institut of the University of Cologne.

22 For an exhaustive overview of Thomas's sources, cf. D.E. Sharp, Franciscan Philosophy at Oxford (New York: Russell, 1964), p. 53-55.

23 The philosophical authorities explicitly mentioned in the first book are: Aristotle (421 quotations); Plato (211); Averroes (156); Avicenna (144); Hermes Trismegistus (106); Algazel (89); Maimonides (6o); Avicebron (46); Themistius (34). The theological authorities explicitly mentioned in the first book are: Augustine (236); Boethius (81); Dionysius 
These figures alone might be sufficient to prove Thomas' deep interest in the Hellenic and Arabic philosophy. These data become even more interesting if we try to understand the true nature of the Sapientiale.

The method and purpose of the work are openly declared by the author in the first four introductive chapters: first and foremost, the Sapientiale is a work written by a theologian for the purpose of coherently systematizing the doctrines of the philosophers in the clear attempt to realize a synthesis of Christian and philosophical wisdom.

Has autem utilitates et causas advertens ego minorum minimus elegi opus sudore plenum, et propter intellectus nostri imbecillitatem et ipsius operis difficultatem, de libris philosophicis congregare aliqua, que dixerunt de creatore et creaturis, quod estimo difficile propter eam, que paucis facta est, philosophie communicationem, verorum cum falsis confusionem, scientie sub verbis absconsionem. ${ }^{24}$

In the dense interweaving of sources that constitutes his work, Thomas proceeds evenly towards a specific goal. His intention is to demonstrate that, even though the source of all knowledge is one, the truth can manifest itself in two ways: in an authoritative way, that is, through the Holy Scripture, and in a rational way, that is, through philosophical inquiry. There is, however, a distinction between theological, authoritative wisdom and philosophical, rational wisdom, since theology and philosophy are separate and distinct in their methodology. And if authoritative knowledge secundum traditionem auctoritatis allows a broad participation of human beings in wisdom, so much so that many may be wise and know the contents of revelation, rational knowledge is a difficult task: only few may have access to and acquire this wisdom secundum probationem rationis. That is why it is said that there are not many who are wise:

Nempe, cum sint due species sapientie, sicut dicit Rabbi Moses cap. 89, una, que est secundum traditionem auctoritatis, et hec dicitur legis, alia secundum probationem rationis, possibile est, quod multi sunt sapientes

Ps Areopagita (41); Gregory the Great (16); Anselm (13); John Damascene (7); Bernard of Clairvaux (3). The prevalence of philosophical sources over theological sources has already been noted by Sharp, Franciscan Philosophy, p. $5^{\circ}$.

24 Thomas of York, Sapientiale, lib. I, c. 3, Firenze, Biblioteca Nazionale Centrale, Conv. Soppr. A.vi.437 (F), f. 4rb; Vaticano (Città del), Biblioteca Apostolica Vaticana, Vat. lat. 4301 (v), f. 4va; Vaticano (Città del), Biblioteca Apostolica Vaticana, Vat. lat. 6771 (R), f. 16va. 
priori modo et pauci vero posteriori modo, et propter hoc dictum est, quod non multi sapientes. ${ }^{25}$

The English Franciscan does not at all content himself with delimiting the fields of investigation and fixing precise rules for the non-interference of theology and philosophy. Rather, he establishes a real hierarchy, in which greater value is attributed to rational investigation than to pure and simple belief in the precepts of faith. Human beings are like the servants described by Moses Maimonides in the third book of his Dux neutrorum: some servants are so distant from the king's palace that they cannot see the walls; others not only enter the king's palace, but may also look directly into the king's face. The latter are those who are advanced in philosophical studies and perfect in every science. The approach to the creator is achieved only through perfection in the sciences, so that only those who perfectly master the sciences may address the king and see his face:

Tertia causa liquet per parabolam, quam super hoc ponit Rabbi Moyses cap. 82 comparans Deum regi sedenti in sua munitione, servorum cuius quidam sunt extra civitatem, quidam intra, et horum, qui sunt intra, quidam vertunt dorsum ad palatium regis et quidam faciem et ad ipsum tendunt, ut possint regi appropinquare et ei assistere, et horum quidam numquam viderunt murum [...]. Nam quamdiu studueris in disciplinalibus et dialectica, circuis portam; cum intellexeris naturalia, intrasti munitionem et ambulas per atrium; cum autem intellexeris spiritualia, intrasti domum, sed nondum vidisti regem, quousque in hiis omnibus perfectus per omnes cogitationes et actus intenderis in creatorem et omnibus aliis postpositis posueris omnia opera intellectus tui ad intelligendum essentiam creatoris, quod, cum feceris, videbis faciem regis, hoc est regem in decore suo, sicut dixit Ysaias: 'regem in decore suo videbunt'. Vide igitur, qualiter per scientiarum perfectionem maior est appropinquatio ad creatorem, ut soli perfecto liceat alloqui regem et videre faciem eius. ${ }^{26}$

There is, therefore, no need for a divine intervention into human life. Thanks to their own intellectual faculty, human beings alone are responsible for the perfection of their own nature. Human beings can emancipate themselves from bestiality and, by their own effort, obtain the dignity of humanity (dignitatis humane adeptio). The dignity and the superiority of the human beings over

25 Thomas of York, Sapientiale, lib. I, c. 3, F, f. 3va; v, f. 3vb; R, f. $15 \mathrm{vb.}$

26 Thomas of York, Sapientiale, lib. I, c. 3, F, f. 4ra; v, f. 4rb; R, f. 16rb. 
other animals depends exclusively on their wisdom and cognition, which is an instrument of reason.

Utilitas omnium scientiarum est acquisitio perfectionis humane preparantis eam in effectu ad futuram felicitatem. [...] Et hec perfectio tribus modis declarari potest esse per sapientiam. Nam per sapientiam est humane creationis consummatio, ab animalitate elongatio et dignitatis humane adeptio. [...] Nam sicut dicit Albumasar I tract. diff. 5, 'dignitas hominis super cetera animalia non est nisi per sapientiam et cognitionem, que est instrumentum rationis, per cognitionem quidem rerum, que fuerunt et que future sunt'. Unde nisi esset sapientia, non esset homini hec dignitas et ideo, 'quanto magis auxerit homo scientiam, tanto magis augebit prolongationem a ceteris animalibus', 'et quanto plus minuitur sapientia, tanto magis augebit ceteris animalibus propinquitatem'. Et 'inter homines, qui fuerit maior sapientia et ratione, ipse erit ceteris dignior humanitate. ${ }^{27}$

Beatitude, through which the human being becomes god by means of participation, ${ }^{28}$ is not the consequence of a divine illumination or of a divine gift, but the result of an intellectual human act, as Thomas argues in a long quotation from the Prologue to Book vili of Averroes' Commentary on the Physics, a text that remained almost unknown throughout the Middle Ages: ${ }^{29}$

27 Thomas of York, Sapientiale, lib. I, c. 1, F, f. 1va-b; v, f. 2va; R f. 13va-b.

28 Thomas of York, Sapientiale, lib. I, c. 10, F, f. 10vb; v, f. grb; R, f. 24va: Beatitudo vero est ipsa divinitas, unde beatitudinis adeptio beatos deos fieri manifestum est, sed sicut iustitie adeptione iusti, ita divinitatem adeptos deos fieri simili ratione necesse est. Omnis igitur beatus deus, sed natura quidem unus, participatione vero nihil prohibet esse quam plurimos.

29 The Prologue to Book virI of Averroes' commentary on the Physics had a very limited circulation in the Middle Ages. For the transmission of this text, see M. Grignaschi, "Indagine sui passi del «Commento» suscettibili di aver promosso la formazione di un averroismo politico," in L'averroismo in Italia (Roma: Accademia Nazionale dei Lincei, 1979), p. 237288, esp. 258-262; H. Schmieja, "Drei Prologen im grossen Physikkommentar des Averroes," in A. Zimmermann (ed.), Aristotelisches Erbe im arabisch-lateinischen Mittelalter (Berlin / New York: De Gruyter, 1986), p. 175-189. The quotation from the prologue to the VIII Book of the Physics with explicit reference to the ambiguity of the word homo is worthy of note. As Luca Bianchi has already noted (L. Bianchi, "Filosofi, uomini e bruti. Note per la storia di un'antropologia 'averroista,', in Studi sull'Aristotelismo del Rinascimento [Padova: Il Poligrafo, 2003], p. 41-61, esp. p. 50-52), few medievals followed Averroes on this point. The only traces of the presence of this passage in the Latin Middle Ages can be found in: (1) Auctoritates Aristotelis, ed. J. Hamesse (Louvain-la-Neuve / Paris: Publications universitaires / Béatrice-Nauwelaerts, 1974), 3, 229, p. 159, 1. 72-74; (2) Alberich of Reims, Philosophia, ed. R.-A. Gauthier, in R.-A. Gauthier, "Notes sur Siger de Brabant. II. Siger 
Amplius beatitudo secundum Tullium libro I est in completa visione veritatis, cum totos nos ponemus in contemplandis perspiciendisque rebus. Visio autem veritatis sapientia est, quare in ipsa est beatitudinis adimpletio. Hec est enim ultima fortunitas, videlicet esse perfectum ultima perfectione per scientias speculativas secundum Averroem super principium viII Physicorum. Et ideo dicit quod homo dicitur quasi equivoce de tali homine et de aliis hominibus, et hanc fortunitatem dicit esse vitam eternam. ${ }^{30}$

Thomas thus also concurred with Averroes concerning a point that only few medieval theologians agreed to: through an intellectual act, the human being can join and be assimilated to God. ${ }^{31}$ The perfection in the speculative sciences leads the human beings to fully realize their humanity and to obtain eternal life, Thomas maintains following Averroes. Instead of being the point of departure of an anti-Averroist struggle within the Franciscan Order, which had Bonaventure as a protagonist, Thomas of York seems to embrace the 4oth thesis of the list condemned at Paris in 1277: there is no better way to live than philosophically ("Quod non est excellentior status quam vacare philosophiae").

It is therefore not surprising that Berthold of Moosburg - interested in investigating the natural potential of the human intellect rather than in knowing its limits - has relied on Thomas to support the philosophical structure of his own work.

Thomas and Berthold agree on one thing: every divine revelation is not necessarily needed for the well-exercised human intellect. Philosophers, in the absence of any revelation or grace, are able not only to reach a partial

en 1272-1275, Aubry de Reims et la scission des Normands," in Revue des Sciences philosophiques et théologiques 68/1(1984), p. 3-49, esp. p. 29, l. 12-17; (3) Oliver Brito, MS. Oxford, Corpus Christi College 283, f. 151vb (see Gauthier, "Notes sur Siger de Brabant," p. 29); (4) Henry Bate, Speculum divinorum et quorundam naturalium. Parts VI-VII: On the Unity of Intellect. On the Platonic doctrine of the ideas, ed. C. Steel, E. Van der Vyver (Leuven: Leuven University Press, 1994), vi, c. 8, p. 27, l. 93-96. For Henry Bate, cf. G. Guldentops, "Henry Bate's Aristocratic Eudaemonism," in J.A. Aertsen, K. Emery, A. Speer (eds), Nach der Verurteilung von 1277. Philosophie und Theologie an der Universität von Paris im letzten Viertel des 13. Jahrhunderts: Studien und Texte (Berlin: De Gruyter, 2001), p. 657-681, esp. p. 673 .

30 Thomas of York, Sapientiale, lib. I, c. 1, F, f. 1vb; v, f. 2va; R, f. 13 va.

31 Far from being a great opponent of Averroism, Thomas of York constantly refers to Averroes' authority in his work. Averroes' name appears more than 1000 times in the Sapientiale. Very many literal, but implicit quotations can be found in addition to this. Except for the doctrine of the eternity of the world, Averroes is invoked by Thomas only to support his own doctrines. Thomas defends Averroes even when it seems that he denies that God knows singular things. On this point, see n. 35 . 
knowledge of God through an oblique vision, but they can also enjoy a direct and perfect vision of the divine substance.

Thomas of York, Sapientiale, lib. I, Berthold of Moosburg, Expositio, Exp. c. 6, F, f. 6vb; V, f. 6va; R, f. 19va tit. D, p. 40, 1. 111-115

In priori acceptione ascendit anima per laboriosam investigationem dividendo, definiendo, communibus principiis utendo, a notis ad ignota per ratiocinationem progrediendo, a sensibilibus ad intelligibilia transcendendo, et inter intelligibilia ab uno ad aliud ascendendo, quousque perveniat ad ultimum, quod dicit Deum.

Primus autem istorum motuum precipue fuit in philosophis.
Verum, quod per motum obliquum, qui proprius erat philosophorum et erat per laboriosam investigationem primi omnium existentium principii dividendo, definiendo, communibus principiis utendo, a notis ad ignota per ratiocinationem progrediendo, a sensibilibus ad intelligibilia ascendendo et inter intelligibilia ab uno in aliud tendendo, quousque ad simpliciter ultimum perveniatur, ascenderit ipse Proclus in summi boni notitiam, apparet in praesenti libro, ubi in excelsum maximum ascendit per operum conditionem, conditorum gubernationem et contrariorum conciliationem.

The directa Dei visio does not constitute an alternative to the laboriosa investigatio of the philosophers. Quite the contrary, the philosophical pursuit makes the direct insight into God's essence possible:

Secundus autem motus [scilicet rectus - n.n.] paucis datus est, qui fuerunt preter donum fidei. Et si quibus datum est hoc tenuiter propter hoc, quod ille motus non est datus multis in sui excellentia nisi per gratiam specialem aut nonnisi propter precedentem obliquam in Deum animi motionem et hic perfectam, quod paucissimis datum est. ${ }^{32}$

On the basis of a purely rational investigation, it is not only possible to prove God's existence, but also God's unity and trinity. No human being is, indeed, deprived of the knowledge of God. The idea of God is, in fact, naturally present 
in the human intellect. This is one of the doctrines of Thomas of York that interested the Dominican of Moosburg most.

\section{Thomas of York, Sapientiale, lib. I, Berthold of Moosburg, Expositio, c. 5, F, f. 6ra, v, f. 6ra; R, f. 18vb $\quad$ 116C, p. 63, l. 125-131}

Et ex hiis liquet, quod superius dictum est nullum hominum penitus scientia Dei privatum, sed ipsum esse in consensione omnium. Ex quo etiam sequitur ipsum esse naturaliter omni homini impressum ratione, qua dixi tibi:quod enim non est foris acceptum, est intus formatum. Constat autem, quod non, nisi a nature humane formatore, quo formata est ad imaginem Dei secundum intellectum, secundum quod dicit Aristoteles x Ethicorum capitulo 10, quod intellectus est Deo cognatissimus.
Ex quo sequitur necessario ipsum esse, et quod nullus hominum est penitus scientia eius privatus, sed ipsum esse in consensione omnium. Ex quo etiam sequitur ipsum esse naturaliter homini impressum ex ea parte, qua est ad imaginem Dei, sive tale sit unum animae secundum Platonem vel unitio vel unitas secundum Dionysium sive abditum mentis secundum Augustinum sive intellectus secundum Aristotelem x Ethicorum 10 cap., ubi dicit, quod intellectus est Deo cognatissimus.

The very existence of God can be proven on the basis of exclusively rational arguments: "quod igitur Deus sit declaraverunt mundi sapientes multipliciter, videlicet per universalem hominum consensionem, naturalem impressionem, legis nature dictationem."33

For Thomas, whom Berthold follows in this, the cognitive faculties of philosophical reason are not limited to the pure and simple demonstration of God's existence, but also extend to the knowledge of God's particular qualities, such as his uniqueness. And if some false philosophers (philosophantes) state the contrary, Plato's followers maintain the right position: their error consists only in an improper use of terminology (non superstitiosa nisi nomine solum): of Moosburg, Expositio, ed. F. Retucci, 116C, p. 61, l. 71-73. 


\section{Thomas of York, Sapientiale, lib. I, Berthold of Moosburg, Expositio, 114A, c. 10, F, f. 1ova-b; V, f. 9ra; R, f. 24rb p. 4o, l. 10-p. 41, l. 27}

Nam quorundam positio de diis erat superstitiosa et impietate plena, quorundam autem nonnisi nomine solum. Superstitiosorum positio erat, qua ponebant illa corpora visibilia esse deos et hoc multipliciter, quia quidam ponebant corpora artificialia, quidam naturalia esse deos. Et item ponentes corpora artificialia ut ydola esse deos, quidam ponebant per solam humanam fictionem, et hoc vel per poetica figmenta, contra quod agit Plinius De naturali historia II capitulo 7 - nam poetica figmenta humana transferebant ad deos, idest divina, cum tamen melius fuisset, si divina transtulissent ad humana, sicut dicit Tullius De Tusculanis questionibus I y - vel per hominum merita, secundum quod dicit Plinius in eodem, quod deorum nomina ex hominum meritis nata sunt, ad cuius fictionem allexit vel amicorum dilectio vel carorum recordatio vel artificium adinventio vel per hominum merita.

Hee autem omnes positiones superstitiose erant et dampnate apud omnes vere philosophantes, sicut manifestabitur in sermone $D e$ quiditate Dei. Positio deorum non superstitiosa nisi nomine solum erat Platonis et Platonicam philosophiam veraciter sectantium, quippe secundum Hermetem multi dicti sunt dii partecipatione eius, qui omnium maximus est $\langle$ deus $\rangle$ deorum.
De primo notandum, quod positio quorundam de diis, hoc est, quod plures essent dii, erat superstitiosa, quorundam vero non superstitiosa nisi solo nomine. Superstitiosorum positio erat, qua ponebant illa visibilia esse deos, et hoc multipliciter, quia quidam ponebant corpora naturalia, quidam artificialia esse deos. Et item ponentes corpora artificialia ut idola esse deos, quidam ponebant per solam humanam fictionem, et hoc per poetica figmenta, contra quos agit Plinius De naturali historia libro II cap. 7 et est summa rationis suae, quia transferebant humana ad divina, cum deberet fieri econverso. [...]

Hae omnes opiniones superstitiosae erant et damnatae apud omnes vere philosophantes. Positio deorum non superstitiosa nisi nomine solum erat Platonis et Platonicam philosophiam veraciter sectantium, quippe secundum Hermetem multi dicti sunt dii participatione eius, qui omnium est maximus, scilicet deus deorum. 
Finally, philosophical reason is able to access the Trinitarian mysteries. It is not by chance that Berthold, in commenting on Proclus' Proposition 131 ("Omnis deus a se ipso propriam operationem orditur") reports the well-known passage from the Logos teleios that Thomas of York had used in his Sapientiale as an authoritative testimony to the fact that the philosophers succeeded, without any revelation, in grasping the truths of the Trinitarian relationships and the Son's generation: ${ }^{34}$ Plato spoke of the second Person of the Trinity, and Hermes and the Sybil agreed with him. They have also understood that the distinction between the Father and the Son lies not in their essence, but in their person (hec alietas potius in persona quam in essentia).

\section{Thomas of York, Sapientiale, lib. I, Berthold of Moosburg, Expositio, c. 14, F, f. 14ra-b; V, f. 11va-b; R, f. 27va 131B, p. 192, l. 61-p. 193, l. 79}

Ex quibus liquet, quod secundum Platonem due persone invente sunt, Pater videlicet et Filius. Huic autem concordat Hermes, qui Mercurius dicitur, in libro, qui Logosilinus, hoc est verbum perfectum, appellatur. [...] Hec autem Hermetis verba recitat Augustinus in libro suo Contra quinque Hereses, in quo et sermones Sibille recitat sermonibus supradictis concordantes. Alium - inquit - deum dedit hominibus fidelibus colendum. Et ne intelligas alium in essentia, sed potius in persona, subdit: 'Ipsum tuum cognosce dominum Dei filium esse', quem quidem filium 'alio loco symbolon appellat, idest consilium vel consiliarium, secundum quod nominat eum Ysaias consiliarium Deum fortem, et
Ex quibus liquet, quod secundum Platonem duae personae inventae sunt, Pater et Filius. Huic autem concordat Hermes in libro, qui dicitur Logostileos, id est verbum perfectum. $[\ldots]$

Haec autem Hermetis verba recitat Augustinus in libro suo Contra quinque haereses, in quo etiam sermones Sibyllae recitat sermonibus praedictis concordantes. Alium, inquit, deum dedit hominibus fidelibus colendum. Et ne intelligatur alius in essentia, sed potius in persona, subdit: 'Ipsum tuum cognosce dominum Dei filium esse', quem quidem filium 'alio loco symbulon appellat, id est consilium vel consiliarium?. Et prout dicit Trismegistus

34 For the interpretation of this text from the Asclepius, cf. A. Palazzo, "La ricezione di un passo ermetico (Asclepius 8) nel tardo medioevo. Ulrico di Strasburgo, Pietro di Tarantasia, Riccardo di Mediavilla, Bertoldo di Moosburg e Dionigi il Certosino," in T. Iremadze, T. Tskhadadze, G. Kheoshvili (eds), Philosophy Theology Culture. Problems and Perspectives. Jubilee Volume Dedicated to the 75th Anniversary of Guram Tevzadze (Tbilisi: Nekeri-Arche, 2007), p. 104-125. 
(cont.)

\section{Thomas of York, Sapientiale, lib. I, Berthold of Moosburg, Expositio, c. 14, F, f. 14ra-b; V, f. 11va-b; R, f. 27va 131B, p. 192, 1. 61-p. 193, l. 79}

prout dicit Trismegistus Ad Asclepium, Ad Asclepium, quod 'Dei natura quod 'Dei natura consilium est volun- consilium est voluntatis et bonitas tatis et bonitas summa consilium'. Ex summa consilium'. Ex quibus maniquibus manifestum est, quod hec alie- festum est, quod haec alietas potius tas potius in persona quam in essentia in persona quam in essentia intelliintelligenda est. genda est.

And again, Thomas continues, and is in this once more quoted literally by Berthold, philosophers do not limit themselves to talking about the generation of the Son, but also permeate the mysteries with regard to the Holy Spirit. Hermes not only mentioned the third Person, but called it by the correct name. Aethicus Ister described the Trinity in a perfect way (luculenter). Seneca and Cicero treated the operations of the third Person in detail. Averroes also understood and described the Trinity of the divine Persons.

Thomas of York, Sapientiale, lib. I, c. 14, F, f. 14va; V, ff. 11vb-12ra; R, ff. $27 \mathrm{vb}-28 \mathrm{ra}$
Berthold of Moosburg, Expositio, 131B, p. 193, l. 81-p. 194, 1. 117
De tertia persona locuti sunt, licet non adeo manifeste. [...] Istam autem personam tertiam, quam nominavit mediam Porphirius, nominat nomine proprio Trismegistus, videlicet nomine 'Spiritus', cum dicit Ad Asclepium: 'Fuit, inquit, deus et hyle, quem Grece mundum credimus et mundo concomitabatur spiritus vel inerat mundo spiritus' [...]. Quis autem spiritus est iste animas nutriens nisi Spiritus Sanctus, qui tranfert se in animas sanctas, secundum quod dicit Seneca in Epistula 42a? Ex quibus omnibus liquet, quod predicta non possunt
De tertia vero non sunt locuti adeo manifeste. [...] Istam autem tertiam personam, quam Porphyrius nominat mediam, Trismegistus Ad Asclepium exprimit nomine proprio, scilicet Spiritu, cum dicit: 'Fuit, inquit, deus et hyle et mundo concomitabatur spiritus vel inerat mundo spiritus, sed non similiter inerat spiritus mundo ut deo' etc. [...] Quis autem spiritus iste est animas nutriens, nisi Spiritus Sanctus, qui transfert se in animas sanctas, secundum quod dicit 
(cont.)

Thomas of York, Sapientiale, lib. I, c. 14, F, f. 14va; V, ff. 11vb-12ra; R, ff. $27 \mathrm{vb}-28 \mathrm{ra}$
Berthold of Moosburg, Expositio, 131B, p. 193, l. 81-p. 194, l. 117 intelligi de spiritu creato, quia nullus gubernat, implet et vivificat omnia, nisi divinus spiritus, secundum quod premittit Cicero De natura deorum II capitulo 15 de operationibus huius spiritus [...]. Ethicus philosophus Cosmographus in sua Cosmografia, quam transtulit beatus Ieronimus, luculenter exprimit personas tres. [...] Unde et Trinitatem per hanc viam insinuans Porphirius [...] Habes igitur ex hoc sermone Patrem et Filium et voluntatem, quam superius dixit amborum medium, sicut manifestum est ex Augustino De civitate Dei X. Huic autem appropriationi, per quam ostenditur Trinitas personarum in summo Spiritu, attestatur Averroes Super XI Pilosophie prime capitulo 15.
Seneca Epistula 42: 'Sacer', inquit, 'inter nos spiritus sedet malorum bonorumque nostrorum observator et custos; hic prout a nobis tractatus est, ita nos tractat'. Ex quibus omnibus liquet, quod praedicta non possunt intelligi de spiritu creato, quia nullus gubernat, implet et vivificat omnia nisi Spiritus Sanctus sive spiritus divinus, secundum quod praemittit Cicero $D e$ natura deorum libro II cap. 15 de operationibus huius spiritus [...]. Aethicus etiam Cosmographus in sua Cosmographia, quam transtulit beatus Hieronymus, luculenter exprimit tres personas. [...]

In the words of Thomas of York, the myth of ancient wisdom and philosophical revelation live again. Thomas' complete trust in the potentiality of the human intellect and particularly his doctrine of beatitude, considered as the result of an intellectual act, became the characteristic feature of Berthold's Expositio.

In the Sapientiale, Berthold of Moosburg had no difficulty in finding a new definition of philosophy: no longer a science subordinate to theology, but perfect and self-sufficient wisdom. In the recovery of the sapiential tradition of antiquity undertaken by Thomas of York, Berthold traced the conditions to establish the concordance between revelation and philosophy. He does so not by integrating pagan wisdom into the Judaeo-Christian system of revelation, but rather with the purpose of legitimizing the autonomous and independent coexistence of both. In the Sapientiale, Berthold discovered a well-documented history of philosophy written by a theologian in order to legitimize the claims 
of philosophy to be not only an all-encompassing science of reality, but also a valid science of the divine.

\section{The Continuity of the Platonic Tradition}

Thomas of York dedicates his lengthy and sophisticated work to the restoration of the dignity of philosophical wisdom and to the founding of its complete legitimacy. Thanks to his profound analytical abilities, his historical reading is characterized by the awareness that two fundamentally different alternatives characterize the philosophical tradition: Plato, Augustine, Eustratius, and the De causis represent the right option; Aristotle's position is often the wrong one.

Thomas of York corrects Aristotle especially relative to one point: the doctrine of Ideas.

The dissent between Plato and Aristotle on the Ideas is mentioned twice in the course of Thomas' work. In the first book of the Sapientiale, with reference to divine exemplarism, Thomas replies point by point to the arguments that Aristotle had advanced against Plato's doctrine in the Metaphysics. In the third book, this time especially referring to the theme of the homonymy of the term "good", he takes the criticism that Aristotle had leveled against Plato in the Nicomachean Ethics into consideration.

The doctrinal background is, in the first case, well defined: it is a matter of determining precisely how God's knowledge of the creatures can be defined. The problem is not a small one: denying the existence of Ideas either means completely denying God's providence over individual entities or granting God only a universal knowledge and not a particular one. According to Thomas of York, Cicero had fallen prey to the first error in his De divinatione. Averroes, on the contrary, was taken in by the second mistake in his commentary on the eleventh book of the Metaphysics. ${ }^{35}$ Platonic Ideas hence constitute the necessary metaphysical condition for God's particular and not merely universal knowledge and for God's providence concerning individual creatures.

Thomas of York dedicates four dense chapters of his work to Plato's doctrine of Ideas (chapters 27-30 of the first book). In chapter 27, Thomas demonstrates the existence of Ideas (quod idea sit) and deals with their essence or quiddity

35 According to Thomas, Averroes' conclusion concerning the divine knowledge of individuals is fallacious, but only from a formal and linguistic point of view, and not in substance (non tantum in re, sed sermone): cf. Thomas of York, Sapientiale, lib. I, c. 25, F, f. 3ovb; v, f. 24va; R, f. 43ra: Vide ex his sermonibus quomodo non tantum in re, sed sermone expressus est sermo Averrois, quomodo sciat singularia. 
(quid sit idea). In chapter 28 , he focuses on the multiplicity of Ideas and analyzes the relationships between the Idea and sensible being in terms of similarity, causality, essence, and denomination. In chapters 29 and 30, Thomas scrutinizes the arguments put forward by Aristotle against Plato's doctrine of Ideas in Books I and VII of the Metaphysics.

The in-depth analysis of Aristotle's objections by Thomas is clearly subordinate to the clear intention of tracing and neutralizing the reasons for the dissent between Plato and Aristotle.

The arguments Aristotle used to challenge Plato's doctrine of Ideas are manifold. In Thomas' view, however, they can be reduced to a single criticism: according to Aristotle, by assuming the existence of Ideas, Plato has destroyed definition, demonstration and, with them, science, since he considered the Idea to be a singular form and denied the existence of any universal form. It is indeed altogether impossible to consider the Platonic Idea to be universal, as Aristotle points out in his Metaphysics. ${ }^{36}$ On this specific point, however, the reconstruction of Plato's doctrine that Aristotle had offered in his Metaphysics must have seemed inaccurate and misleading to Thomas of York. According to Thomas, Aristotle had actually misunderstood Plato at least on one point, as is confirmed by Eustratius in his commentary on the first and sixth books of the Nicomachean Ethics. Aristotle had considered the universal as something exclusively posterior, that is, as subsequent to the existence of any particular thing: according to Aristotle, the universal is obtained only through abstraction from each particular thing. But Plato, according to the more truthful testimony of his theory offered by Eustratius of Nicaea, had first distinguished three modes of existence for all things:

Oportet te scire in principio sententiam Platonis memoria dignam, quam recitat Commentator super I Ethicorum cap. 7 et vi Ethicorum cap. 8, consonam per omnia sententie sapientis Augustini Super Genesim lib. II cap. $\langle 7\rangle$, cum dicit triplex esse rei, in verbo scilicet increato, in

36 Thomas of York, Sapientiale, lib. I, c. 29, F. 34va; v, ff. 27va-b; R, f. 46rb. For the edition of this text, cf. F. Retucci, “Tommaso di York, Eustrazio e la dottrina delle idee di Platone," in A. Beccarisi, P. Porro, R. Imbach (eds), Per perscrutationem philosophicam. Neue Perspektiven der mittelalterlichen Forschung. Loris Sturlese zum 6o. Geburtstag gewidmet (Hamburg: Meiner, 2008), p. 79-110, here p. 105, 1. 73-83: Scias igitur, quod Aristoteles multis viis contradicit ideis, quarum numerum recolligere est difficile et non multum utile. [...] Igitur de hoc non multum curans dico, quod una de radicibus primis, quas ponit Aristoteles contra ideas, fuit, quod positio idearum negat formam universalem et per consequens scientiam, sicut habetur de hoc ab Aristotele I Metaphysice. Igitur in hoc, quod Plato visus est ponere ideas formas sive intentiones singulares, negavit omnem formam universalem. Quare non erit definitio nec demonstratio, et ita nec scientia, sicut sensui est manifestum, quia species communis definitur, similiter nec demonstratio, cum non sit de singularibus. 
intellectuali natura creata et in materia sive in proprio esse, et quod esse primum est prius duobus sequentibus et esse secundum tertio. ${ }^{37}$

This text is literally quoted by Berthold of Moosburg in the section De ideis of his commentary on Proclus:

De secundo sciendum, quod Eustratius super I Ethicorum cap. 7 et super vi cap. 8 dicit sententiam Platonis de speciebus sive ideis memoria dignam, cum sit consona per omnia sapientiae Augustini, qui in II Super Genesim ad litteram ponit triplex esse rei, in verbo scilicet increato, quod est ars plena omnium rationum viventium et incommutabilium, in intellectuali natura creata et in materia sive in proprio esse. Et dicit, quod esse primum est prius natura duobus sequentibus et esse secundum est prius tertio. ${ }^{38}$

For Plato, and Augustine entirely agreed with him on this, the esse rei exists not only in matter, but also in the uncreated Word (in verbo increato) and in created intellectual nature (in intellectuali natura creata). The doctrine of the triple esse rei, mentioned in this quotation taken from Eustratius, is nothing but a doctrine of Neoplatonic derivation. ${ }^{39}$ Indeed, as recent studies have shown, Eustratius' doctrine of the universal follows a Byzantine tradition that was deeply influenced by the Neoplatonic commentators of Aristotle. ${ }^{40}$

According to Thomas, who quotes Eustratius on this issue, Aristotle's mistake consists in having considered the universal as the result of a logicalabstractive process and posterior to the esse rei extra in materia, and therefore as produced by abstraction from matter. Plato, and Augustine with him, instead describes the forms contained in the intellect as something prior and more

37 Thomas of York, Sapientiale, lib. I, c. 29, F, ff. 34vb-35ra; v, f. 27vb; R, f. 46va. For the edition of this text, cf. Retucci, "Tommaso di York, Eustrazio e la dottrina delle idee di Platone", p. 107, l. 130-135.

38 Berthold of Moosburg, Expositio super Elementationem theologicam Procli. Propositiones 160-183, eds U.R. Jeck, I.J. Tautz (Hamburg: Meiner, 2003), 178B, p. 19o, l. 56-63.

39 For the Neoplatonic influences on the doctrine of the threefold state of the universal in Eustratius, cf. L. Benakis, "The Problem of General Concepts in Neoplatonism and Byzantine Thought," in D.J. O'Meara (ed.), Neoplatonism and Christian Thought (Albany: State University of New York Press, 1982), p. 75-86; K. Giocarinis, "Eustratios of Nicea's Defense of the Doctrine of the Ideas," in Franciscan Studies 24(1964), p. 159204; K. Ierodiakonou, "Metaphysics in the Byzantine Tradition. Eustratios of Nicea on Universals," in Quaestio 5(2005), p. 67-82. 
noble than the forms contained in matter. ${ }^{41}$ The universality that Plato speaks of has nothing to do with the universality considered in logicis speculationibus, as in Aristotle. The universal of Plato is not a logical universal, but an intellectual universal, that is, something substantial that supports other things, which are made according to it: "non intelligibiliter, ut universale logicum, sed intellectualiter". The same text is found in Berthold, who does not limit himself to passively copying the sources cited by Thomas, but reads them first-hand, checks them and completes them, as can be seen with a view to the quotation from Eustratius.

\section{Thomas of York, Sapientiale, lib. I, Berthold of Moosburg, Expositio, 177I, c. 29, p. 109-110, 1. 215-223 p. 183-184, 1. $335^{-349}$}

Praeterea scire debes, quod quando Plato dicit ideas universalia et tota, non intelligit, quod idea sit universale sicut 'universale' sumitur 'in logicis speculationibus', prout dicit Commentator super I Ethicorum cap. 7, quia 'illic' est sermo de universali, quod 'de multis dicitur et est posterius generatione, hic autem, quod ante multa velut praesubsistens eis et illis ad ipsum recipientibus subsistentiam'.
Ex praemissis elicitur tertium, scilicet quod, quando species dicuntur universales, non intenditur de universalitate, prout universale sumitur in logicis speculationibus, secundum quod dicit Eustratius Super I Ethicorum cap. 7: Illud 'quidem enim, de multis dicitur et est posterius generatione, hoc autem, quod ante multa velut praesubsistens eis et illis ad ipsum recipientibus subsistentiam. Ita enim qui circa Platonem rationes quasdam inducentes enhypostatas, id est per se subsistentes divinas intellectuales, ad quas dicebant omnia materialia esse et fieri, quas et species et ideas vocabant et tota et universalia, praesubsistentes quidem his, quae in corporibus sunt, speciebus, separatas autem ab his omnibus, in conditoris' 'mente existentes, altera quaedam secundum ipsas

41 Thomas of York, Sapientiale, lib. I, c. 29, F, f. 34vb; v, f. 27vb; R, f. 46va (cf. Retucci, "Tommaso di York, Eustrazio e la dottrina delle idee di Platone", p. 107, l. 146-154: Nam Aristoteles estimavit esse rei in anima aut intellectu posterius esse rei extra in materia utpote generatum ex ipsa, et esse illud in mente esse universale. [...] Plato vero e contrario credidit quod species rei in anima est prior ea que est in re extra, quia que fiunt ex ablatione, idest abstractione, posteriora sunt et per consequens deteriora naturalibus et sensibilibus uptote generationem ex ipsis habentia.) 
(cont.)

Thomas of York, Sapientiale, lib. I, Berthold of Moosburg, Expositio, 177I, c. 29, p. 109-110, 1. 215-223 p. 183-184, 1. 335-349

Ideo igitur ideae 'dicebantur uni- in materia figurantes. Universalia autem versalia et tota, quia unumquo- et tota haec dicebantur, quoniam unumdque illorum unum ens habet quodque illorum unum ens habet multa multa ex illo et secundum illud ex illo et secundum illud facta in corpore facta sunt'; 'universale quidem et totum non intelligibiliter ut universale logicum, sed intellectualiter. Universale quidem subsistens multis separabiliter, quae secundum illud facta sunt'. et materialia, ad quae illud universale et totum dicebatur non intelligibiliter ut universale logicum, sed intellectualiter, universale quidem velut praesubsistens multis separabiliter, quae secundum' ipsum 'facta sunt'. Haec Eustratius.

According to Thomas (and, consequently, for Berthold), the reason for the disagreement between Plato and Aristotle is thus only Aristotle's coarse misunderstanding of Plato's doctrine of Ideas.

Aristotle's misreading is neutralized by Thomas - and Berthold follows him in this -, once again by appealing to the authority of Eustratius, who opposed the Neoplatonic doctrine that establishes the existence of innate universal forms in the soul to Aristotle's arguments. Eustratius' direct source concerning this point is Proclus' commentary on Plato's Parmenides: ${ }^{42}$

Unde cum secundum Platonem anima est multo melior natura et singularibus et sensibilibus, inconveniens est ipsam habere in se ipsa rationes sive species subsistentes et non habere ipsas ante sensibilia inherentes sibi, rationabiliter et animaliter, hoc est secundum rationem naturalem ipsius anime, cum necesse est ipsam habere eas meliores et natura priores. $^{43}$

42 M. Trizio, "Dissensio philosophorum. Il disaccordo tra Platone e Aristotele nei commenti filosofici di Eustrazio di Nicea († ca. 1120)," in A. Palazzo (ed.), L'antichità classica nel pensiero medievale (Porto: Fédérations Internationale des Instituts d'Études Médiévales, 2011), p. 17-37.

43 Thomas of York, Sapientiale, lib. I, c. 29, p. 107, l. 155-159. Cf. also Berthold of Moosburg, Expositio, 178B, p. 191, 1. 84-88: Unde cum secundum Platonem anima sit multo melior natura et singularibus et sensibilibus, inconveniens est ipsam habere in se ipsa rationes sive species subsistentes et non habere ipsas ante sensibilia inhaerentes sibi rationabiliter 
The consequences of such an interweaving of sources are very clear: quoting Eustratius, who in turn quotes Proclus, Thomas of York unconsciously defends a form of Neoplatonism that heavily relies on Proclean philosophy. It is therefore no coincidence that the defense of Plato's doctrine of Ideas, as elaborated in the Sapientiale, found, more than seventy years after its composition, a careful reader in Berthold of Moosburg, the commentator of Proclus. Berthold's commentary on propositions 176 and 178 , dedicated to the doctrine of Ideas, is neither an implicit reference to Dietrich's doctrine of universals nor an allusion to Avicenna's doctrine mediated by Albert the Great, as Burkhard Mojsisch believed. ${ }^{44}$ Propositions 176 and 178 of the Expositio consist of long literal quotations from the Sapientiale of Thomas of York (see Appendix, VII, 13-32).

The threefold distinction of the esse rei and, moreover, the distinction between logicalia and intellectualia established by Berthold are not, as Alain de Libera maintained, the most characteristic doctrines of the so-called "school of Cologne", which Berthold inherited from Dietrich and Albert. ${ }^{45}$ Instead, it is a doctrine that Berthold discovered in the Sapientiale of Thomas of York, in which, through Eustratius, Proclean philosophy is tacitly revived. ${ }^{46}$

In reconstructing the continuity of the Platonic tradition, Thomas went far beyond his contemporaries. According to him, there is a fil rouge that runs through the history of philosophy and links Plato, Augustine, and the Liber de causis. This is particularly evident relative to the doctrine of Ideas: Plato and Augustine explicitly agree on the existence of this type of universal form in the soul; both Plato and Augustine then stand in open contrast to Aristotle. The Platonic-Augustinian doctrine is, however, confirmed by the Liber de causis, in which the existence of universal forms in the intellect is clearly established:

et animealiter, hoc est secundum rationem naturalem ipsius animae, cum necesse sit, ut inferius apparebit, ipsam habere eas meliores et natura priores.

44 B. Mojsisch, "Aristoteles' Kritik an Platons Theorie der Ideen und die Dietrich von Freiberg berücksichtigende Kritik dieser Kritik seitens Bertholds von Moosburg," in K.-H. Kandler, B. Mojsisch, F.B. Stammkötter (eds), Dietrich von Freiberg. Neue Perspektiven seiner Philosophie, Theologie und Naturwissenschaft (Amsterdam / Philadelphia: Grüner, 1999), p. $267-281$.

45 A. de Libera, Métaphysique et noétique. Albert le Grand (Paris:Vrin, 2005), p. 226-227; A. de Libera, "Théorie des universaux et réalisme logique chez Albert le Grand," in Revues des Sciences Philosophiques et Théologiques 65(1981), p. 55-74; A. de Libera, "Albert le Grand et le Platonisme. De la doctrines des Idées à la théorie des trois états de l'Universel," in E.P. Bos, P.A. Meijer (eds), On Proclus and his Influence in Medieval Philosophy (Leiden / New York / Köln: Brill, 1992), p. 89-119.

46 On this point see I. Zavattero, "Proclus, Eustrate de Nicée et leur réception aux XIII ${ }_{-}$ XIV e siècles," in D. Calma (ed.), Reading Proclus and the Book of Causes. Volume 1 (Leiden: Brill, 2019), p. 327-351, esp. p. 335-347. 
Dico igitur tibi secundum sententiam Augustini et Platonis, quod triplex est esse rei, videlicet in mente divina, in intellectuali natura, in propria existentia; et quod esse eius in natura intellectiva, anima videlicet et intelligentia, medium est inter esse primum et tertium; et quod omnes forme, que exprimuntur in materia, prius naturaliter sunt concreate in intelligentia sive anima, quoniam natura pares sint. Et hoc est consonum propositioni De causis, que dicit quod omnis intelligentia plena est formis. ${ }^{47}$

Following the fil rouge of the Platonic tradition, Thomas went also far beyond the texts that were at his disposal. In his defense of the intelligible world, which links Plato to Augustine, Thomas of York explicitly quotes Eustratius of Nicaea, who silently borrows the doctrine of the existence of a triplex esse rei from Proposition 67 of the Elementatio theologica. 48 The result of this maze of quotations is evident: Thomas - by quoting Eustratius and by revealing his proximity to Plato, Augustine, and the De causis - concludes by unconsciously assimilating the De causis to its original source, namely, the Elementatio theologica. ${ }^{49}$

Thanks to the new material made available in translation from Greek into Latin, especially by his mentor Robert Grosseteste, and thanks to his profound analytical attitude, Thomas of York succeeds in reconstructing the contours of the Platonic tradition - a tradition he vigorously counterposes to the Aristotelian one.

Concerning many points, Thomas of York criticizes and corrects Aristotle's thought and contrasts it with a Platonic option that has been reconstructed on the basis of an indirect tradition: the De causis, Augustine, and the Byzantine commentators. The very same intention led Berthold of Moosburg, a few decades later, to compose his Platonic enterprise. He wanted to trace the points of divergence between the Platonic and the Aristotelian tradition and demonstrate the clear superiority of the former over the latter. Not by chance is the Expositio aimed at recovering Platonism as a unified current of thought that

47 Thomas of York, Sapientiale, lib. vi, c. 26, F, f. 205va; v, f. 166ra; R, f. 216ra. Concerning the influence of the De causis on the Sapientiale, cf. F. Retucci, "The De causis in Thomas of York", in D. Calma (ed.), Reading Proclus and the Book of Causes. Volume 1 (Leiden: Brill, 2019), p. 70-119.

48 On this point, cf. C. Steel, "Neoplatonic Sources in the Commentaries on the Nicomachean Ethics by Eustratius and Michael of Ephesus," in Bulletin de Philosophie Médiévale 44(2002), p. 51-57, at p. 53-54; S. Gersh, "Universals, Wholes, Logoi: Eustratios of Nicaea's Response to Proclus' Elements of Theology," in D. Calma (ed.), Reading Proclus and the Book of Causes. Volume 2 (Leiden: Brill, 2020), p. 40-55.

Cf. Retucci, "The De causis in Thomas of York," p. 89-92. 
includes Dionysius, Proclus, the De causis, and Eustratius of Nicaea, among others. This unified Platonic tradition is proposed, in Berthold's work, as a triumphant antagonist to a form of eclectic Aristotelianism. Berthold often realizes his project of writing a comprehensive and erudite encyclopedia of Platonism simply by integrating Proclean material into the long excerpts he takes from the Sapientiale. ${ }^{50}$

\section{Thomas of York, Sapientiale, lib. III, Berthold of Moosburg, Expositio, c. 13, p. 167-168, 1. 28-51 151D, p. 137, l. 184-p. 138, 193}

Hii enim agentes quatuor operationem habent, communem et specialem. Communem, quoniam in singulis operibus nature concurrunt omnium actiones, sicut supra dictum est, quomodo omnis forma inducitur in materia per omnes causas medias usque ad primam, et sic per ipsam plus effluentem ( $c f$. De causis, 1 ) $[\ldots]$

Habent et specialem, sicut superior respectu inferioris. Nichil enim habet inferior quod non superior instar ordinum angelicorum, sicut ponit Sapientia Christianorum; habet tamen superior proprium, quod non habet inferior vel ad minus non in eadem plenitudine; igitur actio virtutis elementi aut elementati actio est virtutum omnium superiorum.
De primo sciendum, quod ipsorum deorum quaedam operationes sunt communes, quaedam speciales.

Communes, inquantum in singulis operibus naturae concurrunt omnium actiones. Omnis enim forma inducitur in materia per omnes causas medias essentialiter sibi subordinatas usque ad prime bonum inclusive. 'Omne enim, quod a secundis producitur, et a prioribus et causalioribus producitur eminentius' per 56 .

Speciales vero sive proprie operationes sunt, quas habent superiora respectu inferiorum, quidquid enim operatur inferius haec et operatur superius, sed non econverso. Et de istis operationibus dicitur, quod 'omnis deus a se ipso orditur propriam operationem' per 131.

Although little is known about Berthold's biography, as has been said at the beginning of this study, it is clear that he was active within the context of the German Dominican order. The first certain biographical data on his life, however, places Berthold in a milieu far away from Cologne. In the proceedings of 
the General Chapter of the Teutonic Province held in Friesach in 1315, the decision to send Berthold to Oxford is stated: "Mictimus in Angliam fr. Berchtoldum de Mospurg". ${ }^{11}$ At Oxford, Berthold discovered how thoroughly the German Dominican tradition, initiated by Albert, and the English Franciscan tradition, introduced by Robert Grosseteste, converged. With a view to the revival of the ancient sapiential heritage and the defense of the Platonic tradition, both of which would come to characterize his commentary on Proclus' Elements of Theology, Berthold could therefore not only be considered the spokesman for the main features of the so-called Deutsche Dominikanerschule, that is, the school of Albert the Great, Dietrich of Freiberg, and Ulrich of Strassburg. With regard to the harsh criticism of Aristotle, the defense of the unitary position offered by Christianity and Platonism and, at the same time, the recovery of ancient pagan wisdom, the Dominican of Moosburg had found a constant point of reference in another work: the Sapientiale of Thomas of York.

\section{Appendix \\ Thomas of York's Sapientiale in Berthold's Commentary}

Thomas of York, Sapientiale, Firenze, Biblioteca Nazionale Centrale, Conv. Soppr. A.vi.437 (= F).

Thomas of York, Sapientiale, Vaticano (Città del), Biblioteca Apostolica Vaticana, Vat. lat. $4301(=\mathrm{V})$.

Thomas of York, Sapientiale, Vaticano (Città del), Biblioteca Apostolica Vaticana, Vat. lat. $6771(=\mathrm{R})$.

I. Berthold of Moosburg, Expositio super Elementationem theologicam Procli. Prologus. Propositiones 1-13, eds M.R. Pagnoni-Sturlese, L. Sturlese (Hamburg: Meiner, 1984).

1. Prol. 1 (p. 5, l. 13-16): cf. Sapientiale, lib. I, c. 7, F, f. $7 \mathrm{va}^{52}$

2. Prol. 1 (p. 5, l. 16-19): cf. Sapientiale, lib. I, c. 4, F, f. 5rb

3. Prol. 1 (p. 5, l. 19-22): cf. Sapientiale, lib. I, c. 3, F, f. 3va

4. Prol. 1 (p. 6, l. 34-36): cf. Sapientiale, lib. I, c. 5, F, f. 5vb

5. $\quad$ Prol. 8 (p. 14, l. 296-299): cf. Sapientiale, lib. viı, c. 1, F, f. 212rb

$5^{1}$ Cf. Th. Kaeppeli, "Ein Fragment der Akten des in Friesach 1315 gefeierten Kapitels des Provinz Teutonia," in Archivum Fratrum Praedicatorum 48(1978), p. 71-75.

$5^{2}$ All references to the Sapientiale are to the manuscript: Firenze, Biblioteca Nazionale Centrale, Conv. Soppr. A.vi.437 (F). Starting from Book II the manuscript Città del Vaticano, Biblioteca Apostolica Vaticana, Vat. lat. 43 o1 has a different book numbering (cf. F. Retucci, "The Sapientiale of Thomas of York: The Fortunes and Misfortunes of a Critical Edition", in Bulletin de Philosophie Médiévale 52 (2010), p. 133-16o, esp. p. 140-142. In this appendix these differences have been indicated in brackets. 
6. Prol. 9 (p. 15, l. 324-327): cf. Sapientiale, lib. viI, c. 1, F, f. 212rb

7. $\quad$ Prol. 9 (p. 15, l. 328-332): cf. Sapientiale, lib. viI, c. 2, F, f. 212vb

8. Prol. 9 (p. 15, l. 338-339): cf. Sapientiale, lib. VII, c. 1, F, f. 212rb

9. $\quad$ Prol. 9 (p. 15, l. 342-p. 16, l. 348): cf. Sapientiale, lib. I, c. 37, F, 42rb; II, 2, F, f. 51ra

10. Prol. 10 (p. 16, l. 364-375): cf. Sapientiale, lib. viı, c. 1, F, f. 212rb

11. Prol. 11 (p. 17, l. 402-p. 18, 1. 406): cf. Sapientiale, lib. VII, c. 1, F, f. 212rb

12. Exp. tit. C (p. 39, l. 73-78). Cf. Sapientiale, lib. I, c. 6, F, f. 6vb

13. Tit. D (p. 40, l. 111-115): cf. Sapientiale, lib. I, c. 6, F, f. 6vb

14. Tit. D (p. 40, l. 119-123): cf. Sapientiale, lib. I, c. 7, F, f. 7va

15. Tit. D (p. 40, l. 126-p. 41, l. 144): cf. Sapientiale, lib. I, c. 7, F, f. 8ra-b

16. Tit. E (p. 41, l. 163-166): cf. Sapientiale, lib. I, c. 1, F, ff. 1rb

17. Tit. E (p. 42, l. 175-180): cf. Sapientiale, lib. I, c. 1, F, ff. 1rb

18. Tit. E (p. 42, l. 181-195): cf. Sapientiale, lib. I, c. 1, F, ff. 1rb-va

19. Tit. F (p. 43, l. 208-211): cf. Sapientiale, lib. I, c. 3, F, f. 3ra-b

2o. Tit. K (p. 47, l. 368-p. 48, l. 383): cf. Sapientiale, lib. I, c. 5, F, f. 5 va

21. Tit. L (p. 49, l. 415-419): cf. Sapientiale, lib. I, c. 9, F, f. 1ovb

22. Tit. L (p. 49, l. 431-439): cf. Sapientiale, lib. I, c. 5, F, f. 5 va

23. Tit. L (p. 5o, l. 463-468): cf. Sapientiale, lib. I, c. 1, F, f. 1va-b

24. Praeamb. A (p. 54, l. 32-p. 56, l. 10o): cf. Sapientiale, lib. v, c. 23 (Città del Vaticano, Biblioteca Apostolica Vaticana, Vat. lat. 4301: lib. III, c. 23), F, ff. 166vb-167rb

25. Praeamb. B (p. 57, l. 140-157): cf. Sapientiale, lib. v, c. 23 (Città del Vaticano, Biblioteca Apostolica Vaticana, Vat. lat. 4301: lib. III, c. 23), F, f. 167vb

26. Praeamb. B (p. 59, l. 205-108): cf. Sapientiale, lib. v, c. 24 (Città del Vaticano, Biblioteca Apostolica Vaticana, Vat. lat. 4301: lib. III, c. 24), F, f. 168vb

27. Praeamb. B (p. 61, l. 297-303): cf. Sapientiale, lib. v, c. 25 (Città del Vaticano, Biblioteca Apostolica Vaticana, Vat. lat. 4301: lib. III, c. 23), F, f. 17ora

28. Praeamb. C (p. 63, l. 355-370): cf. Sapientiale, lib. v, c. 24 (Città del Vaticano, Biblioteca Apostolica Vaticana, Vat. lat. 4301: lib. III, c. 24), F, f. 169ra-b

29. Praeamb. C (p. 66, 1. 462-48o): cf. Sapientiale, lib. v, c. 23 (Città del Vaticano, Biblioteca Apostolica Vaticana, Vat. lat. 4301: lib. III, c. 23), F, f. 168ra-b

3o. Praeamb. C (p. 67, l. 504-513): cf. Sapientiale, lib. v, c. 23 (Città del Vaticano, Biblioteca Apostolica Vaticana, Vat. lat. 4301: lib. III, c. 23), F, f. 168rb

31. Praeamb. C (p. 68, l. 541-548): cf. Sapientiale, lib. v, c. 23 (Città del Vaticano, Biblioteca Apostolica Vaticana, Vat. lat. 4301: lib. III, c. 23), F, f. 168rb

32. Prop. 1 E (p. 78, l. 253-p. 79, l. 271): cf. Sapientiale, lib. v, c. 1 (Città del Vaticano, Biblioteca Apostolica Vaticana, Vat. lat. 4301: lib. III, c. 1), F, f. 138ra; Thomae Eboracensis Sapientiale. Liber III. Cap. 1-20, p. 5, 1. 47-49; p. 6, 1. 59-68

33. Prop. ${ }_{3}$ C (p. 96, l. 148-151): cf. Sapientiale, lib. II, c. 30 (Città del Vaticano, Biblioteca Apostolica Vaticana, Vat. lat. 4301: lib. II, c. 29), F, f. $87 \mathrm{vb}$

34. Prop. 4A (p. 102, l. 48-57): cf. Sapientiale, lib. II, c. 11 (Città del Vaticano, Biblioteca Apostolica Vaticana, Vat. lat. 4301: lib. II, c. 10), F, f. 69rb 
35. Prop. 4A (p. 102, l. 58-p. 103, l. 87): cf. Sapientiale, lib. II, c. 20 (Città del Vaticano, Biblioteca Apostolica Vaticana, Vat. lat. 4301: lib. II, c. 19), F, ff. 77ra-va

36. Prop. 4E (p. 109, l. 298-p. 110, l. 339): cf. Sapientiale, lib. v, c. 1 (Città del Vaticano, Biblioteca Apostolica Vaticana, Vat. lat. 4301: lib. III, c. 1), F, f. 138ra

37. Prop. 5D (p. 120, 1. 264-270): cf. Sapientiale, lib. II, c. 17, F, f. 75va

38. Prop. 6A (p. 127, l. 11-20): cf. Sapientale, lib. II, c. 2, F, f. 51va

39. Prop. 6A (p. 127, l. 21-p. 128, l. 33): cf. Sapientiale, lib. vII, c. 2, F, f. $57 \mathrm{rb}$

4O. Prop. 6A (p. 128, l. 38-p. 129, l. 72): cf. Sapientiale, lib. viI, c. 2, F, f. 57 va

41. Prop. 6B (p. 129, l. 95-102): cf. Sapientiale, lib. viI, c. 2, F, f. 57 va

42. Prop. 6B (p. 130, l. 104-111): cf. Sapientiale, lib. vi , c. 3, F, f. 58rb

43. Prop. 6D (p. 131, l. 144-148): cf. Sapientiale, lib. vII, c. 2, F, f. 57vb

44. Prop. 6E (p. 131, l. 150-16o): cf. Sapientiale, lib. viI, c. 6, F, f. 62rb

45. Prop. 6E (p. 131, l. 162-169): cf. Sapientiale, lib. viı, c. 6, F, f. 62ra

46. Prop. 6E (p. 132, l. 171-173): cf. Sapientiale, lib. viI, c. 6, F, f. 62ra

47. Prop. 6E (p. 132, l. 179-p. 133, l. 231): cf. Sapientiale, lib. viI, c. 6, F, ff. 62rb-va

48. Prop. 6E (p. 132, l. 202-p. 133, l. 208): cf. Sapientiale, lib. I, c. 14, F, f. 14va

49. Prop. 7 E (p. 152, l. 493-p. 154, l. 554): cf. Sapientiale, lib. v, c. 8 (Città del Vaticano, Biblioteca Apostolica Vaticana, Vat. lat. 4301: lib. III, c. 8), F, ff. 145va-146ra; Thomae Eboracensis Sapientiale. Liber III. Cap. 1-20, p. 94, 1. 27-p. 100, 1.16o

5o. Prop. 8B (p. 158, l. 50-56): cf. Sapientiale, lib. I, c. 9, F, f. 9va

51. Prop. 9B (p. 170, l. 114-120): cf. Sapientiale, lib. I, c. 6, F, f. 6va

52. Prop. $10 \mathrm{D}$ (p. 182, l. 208-213): cf. Sapientiale, lib. I, c. 31, F, ff. 37vb-38ra

53. Prop. $10 \mathrm{E}$ (p. 183, l. 217-226): cf. Sapientiale, lib. I, c. 31, F, f. 38rb

54. Prop. 11 F (p. 192, l. 261-p. 194, l. 331): cf. Sapientiale, lib. v, c. 8 (Città del Vaticano, Biblioteca Apostolica Vaticana, Vat. lat. 4301: lib. III, c. 8), F, ff. 146rb-va; Thomae Eboracensis Sapientiale. Liber III. Cap. 1-20, p. 101, 1. 179-p. 105, 1. 270

55. Prop. 12A (p. 197, l. 25-p. 198, l. 30): cf. Sapientiale, lib. v, c. 21 (Città del Vaticano, Biblioteca Apostolica Vaticana, Vat. lat. 4301: lib. III, c. 21), F, f. 164ra

56. Prop. 12 C (p. 200, l. 122-p. 201, l.156): cf. Sapientiale, lib. v, c. 21 (Città del Vaticano, Biblioteca Apostolica Vaticana, Vat. lat. 4301: lib. III, c. 21), F, f. 164ra

57. Prop. 12D (p. 201, l. 163-170): cf. Sapientiale, lib. v, c. 25 (Città del Vaticano, Biblioteca Apostolica Vaticana, Vat. lat. 4301: lib. III, c. 25), F, f. 169vb

58. Prop. 12 E (p. 202, l. 175-p. 205, l. 283): cf. Sapientiale, lib. v, c. 25 (Città del Vaticano, Biblioteca Apostolica Vaticana, Vat. lat. 4301: lib. III, c. 25), F, ff. 17ora-va

II. Berthold of Moosburg, Expositio super Elementationem theologicam Procli. Propositiones 14-34, eds L. Sturlese, M.R. Pagnoni-Sturlese, B. Mojsisch (Hamburg: Meiner, 1986).

1. Prop. 15D (p. 19, l. 163-p. 20, l. 189): cf. Sapientiale, lib. III, c. 31 (Città del Vaticano, Biblioteca Apostolica Vaticana, Vat. lat. 4301: lib. IV, c. 31), F, f. 126vb

2. Prop. 16B (p. 26, l. 71-87): cf. Sapientiale, lib. I, c. 17, F, f. 22rb 
3. Prop. 18B (p. 48, l. 157-161): cf. Sapientiale, lib. I, c. 9, F, f. 9va

4. $\quad$ Prop. 21 B (p. 79, l. 138-p. 8o, l. 163): cf. Sapientiale, lib. II, c. 2, F, ff. 51rb-va

5. Prop. ${ }_{21 K}$ (p. 91, l. 554-p. 93, l. 601): cf. Sapientiale, lib. v, c. 14 (Città del Vaticano, Biblioteca Apostolica Vaticana, Vat. lat. 4301: lib. III, c. 14), F, f. 153ra; Thomae Eboracensis Sapientiale. Liber III. Cap. 1-20, p. 180, 1. 9-p. 181, 1. 38

6. Prop. $21 \mathrm{M}$ (p. 94, l. 636-645): cf. Sapientiale, lib. v, c. 16 (Città del Vaticano, Biblioteca Apostolica Vaticana, Vat. lat. 4301: lib. III, c. 16), F, f. 158ra; Thomae Eboracensis Sapientiale. Liber III. Cap. 1-20, p. 222, 1. 144-154

7. Prop. 22D (p. 105, l. 250-26o): cf. Sapientiale, lib. I, c. 10, F, f. $11 v b$

8. Prop. 22D (p. 105, l. 275-p. 106, l. 28o): cf. Sapientiale, lib. I, c. 10, F, f. ura

9. Prop. 22D (p. 106, l. 281-313): cf. Sapientiale, lib. I, c. 10, F, f. 11rb

10. Prop. 22D (p. 107, l. 321-326): cf. Sapientiale, lib. I, c. 10, F, f. 11va

11. Prop. 22 D (p. 107, l. 330-343): cf. Sapientiale, lib. I, c. 10, F, f. 11va

12. Prop. 22 E (p. 107, l. 347-p. 108, l. 374): cf. Sapientiale, lib. I, c. 10, F, f. 11vb

13. Prop. 22 F (p. 108, l. 381-p. 109, l. 387): cf. Sapientiale, lib. I, c. 10, F, f. 11ra

14. Prop. 23 D (p. 116, l. 145-150): cf. Sapientiale, lib. I, c. 31, F, f. $37 \mathrm{rb}$

15. Prop. 23 D (p. 116, l. 172-p. 117, l. 186): cf. Sapientiale, lib. I, c. 31, F, f. 37rb

16. Prop. 23 E (p. 117 , l. 200-p. 118, l. 223): cf. Sapientiale, lib. I, c. 20, F, f. $27 \mathrm{rb}$

17. Prop. 23 E (p. 118, l. 243-p. 119, l. 253): cf. Sapientiale, lib. I, c. 20, F, f. 27 rb

18. Prop. 23 E (p. 119, l. 257-268): cf. Sapientiale, lib. I, c. 20, F, f. $27 \mathrm{rb}$

19. Prop. $23 \mathrm{I}$ (p. 120, l. 315-p. 121, l. 324): cf. Sapientiale, lib. v, c. 14 (Città del Vaticano, Biblioteca Apostolica Vaticana, Vat. lat. 4301: lib. III, c. 14), F, f. 153ra; Thomae Eboracensis Sapientiale. Liber III. Cap. 1-20, p. 180, 1. 17-p. 181, 1. 31

20. Prop. 23I (p. 121, l. 325-340): cf. Sapientiale, lib. v, c. 16 (Città del Vaticano, Biblioteca Apostolica Vaticana, Vat. lat. 4301: lib. III, c. 16), F, f. 157va-b; Thomae Eboracensis Sapientiale. Liber III. Cap. 1-20, p. 218, 1. 53-59

21. Prop. 25A (p. 137, l. 23-27): cf. Sapientiale, lib. I, c. 6, F, f. 6va

22. Prop. 25A (p. 137, l. 28-p. 139, l. 81): cf. Sapientiale, lib. v, c. 26 (Città del Vaticano, Biblioteca Apostolica Vaticana, Vat. lat. 4301: lib. III, c. 26), F, f. 171ra-b

23. Prop. ${ }_{25}$ G (p. 146, l. 328-p. 148, l.387): cf. Sapientiale, lib. v, c. 15 (Città del Vaticano, Biblioteca Apostolica Vaticana, Vat. lat. 4301: lib. III, c. 15), F, f. 156va-b; Thomae Eboracensis Sapientiale. Liber III. Cap. 1-20, p. 206, l. 305-p. 209, l. 365

24. Prop. 25 H (p. 148, l. 395-p. 149, l. 415): cf. Sapientiale, lib. v, c. 15 (Città del Vaticano, Biblioteca Apostolica Vaticana, Vat. lat. 4301: lib. III, c. 15), F, f. 157ra; Thomae Eboracensis Sapientiale. Liber III. Cap. 1-20, p. 210, l. 396-403

25. Prop. 25I (p. 150, l. 448-453): cf. Sapientiale, lib. v, c. 15 (Città del Vaticano, Biblioteca Apostolica Vaticana, Vat. lat. 4301: lib. III, c. 15), F, ff. 157rb-va; Thomae Eboracensis Sapientiale. Liber III. Cap. 1-20, p. 214, 1. 499-p. 215, 1. 508

26. Prop. 26A (p. 153, l. 13-19): cf. Sapientiale, lib. v, c. 9 (Città del Vaticano, Biblioteca Apostolica Vaticana, Vat. lat. 4301: lib. III, c. 9), F, f. 147rb; Thomae Eboracensis Sapientiale. Liber III. Cap. 1-20, p. 116, 1. 145-151 
27. Prop. 26A (p. 154, l. 32-41): cf. Sapientiale, lib. v, c. 9 (Città del Vaticano, Biblioteca Apostolica Vaticana, Vat. lat. 4301: lib. III, c. 9), F, f. 147va; Thomae Eboracensis Sapientiale. Liber III. Cap. 1-20, p. 118, l. 191-p. 119, l. 215

28. Prop. 27 A (p. 162, l. 51-67): cf. Sapientiale, lib. v, c. 12 (Città del Vaticano, Biblioteca Apostolica Vaticana, Vat. lat. 4301: lib. III, c. 12), F, f. 151va; Thomae Eboracensis Sapientiale. Liber III. Cap. 1-20, p. 163, l. 173-p. 164, 1. 207

29. Prop. 28A (p. 171, l. 13-p. 173, l. 76): cf. Sapientiale, lib. I, c. 42, F, ff. 46va-47rb

3o. Prop. 28B (p. 173, l. 95-p. 174, l. 112): cf. Sapientiale, lib. I, c. 42, F, ff. 46vb-47ra

31. Prop. 28B (p. 174, l. 122-124): cf. Sapientiale, lib. I, c. 42, F, f. 47ra

32. Prop. 34A (p. 221, l. 42-63): cf. Sapientiale, lib. v, c. 21 (Città del Vaticano, Biblioteca Apostolica Vaticana, Vat. lat. 4301: lib. III, c. 21), F, f. 165ra

33. Prop. 34A (p. 221, l. 64-p. 223, l. 110): cf. Sapientiale, lib. VI, c. 13 (Città del Vaticano, Biblioteca Apostolica Vaticana, Vat. lat. 43o1: lib. v, c. 13), F, f. $245^{\mathrm{ra}-\mathrm{b}}$

34. Prop. 34A (p. 223, l. 114-126): cf. Sapientiale, lib. VI, c. 13 (Città del Vaticano, Biblioteca Apostolica Vaticana, Vat. lat. 4301: lib. v, c. 13), F, f. 245rb

35. Prop. 34B (p. 224, l.134-p. 227, l. 247): cf. Sapientiale, lib. vi, c. 15 (Città del Vaticano, Biblioteca Apostolica Vaticana, Vat. lat. 4301: lib. v, c. 15), F, ff. 245rb-246vb

III. Berthold of Moosburg, Expositio super Elementationem theologicam Procli. Propositiones 35-65, ed. A. Sannino (Hamburg: Meiner, 2001).

1. Prop. 35B (p. 4, l. 50-59): cf. Sapientiale, lib. v, c. 8 (Città del Vaticano, Biblioteca Apostolica Vaticana, Vat. lat. 4301: lib. III, c. 8), F, f. 145va-b; Thomae Eboracensis Sapientiale. Liber III. Cap. 1-20, p. 94, 1. 35-p. 95, 1. 6o

2. Prop. 35C (p. 5, l. 106-p. 7, l. 155): cf. Sapientiale, lib. VI, c. 17 (Città del Vaticano, Biblioteca Apostolica Vaticana, Vat. lat. 4301: lib. v, c. 17), F, ff. 247rb-va

3. Prop. 35D (p. 7, l. 164-p. 8, l. 171): cf. Sapientiale, lib. VI, c. 17 (Città del Vaticano, Biblioteca Apostolica Vaticana, Vat. lat. 4301: lib. v, c. 17), F, f. $247 \mathrm{va}$

4. Prop. 36C (p. 18, l. 112-114): cf. Sapientiale, lib. I, c. 7, F, f. 24vb

5. $\quad$ Prop. 38F (p. 29, l. 98-p. 30, l. 101): cf. Sapientiale, lib. I, c. 6, F, f. 6rb

6. Prop. 59A (p. 163, l. 11-p. 164, l. 47): cf. Sapientiale, lib. v, c. 28 (Città del Vaticano, Biblioteca Apostolica Vaticana, Vat. lat. 4301: lib. III, c. 28), F, ff. 173rb-174ra

7. Prop. 59B (p. 164, l. 51-57): cf. Sapientiale, lib. v, 28 (Città del Vaticano, Biblioteca Apostolica Vaticana, Vat. lat. 4301: lib. III, c. 28), F, f. 174rb

IV. Berthold of Moosburg, Expositio super Elementationem theologicam Procli. Propositiones 66-107, ed. I. Zavattero (Hamburg: Meiner, 2003).

1. Prop. 67 C (p. 9, l. 6o-p. 10, l. 89): cf. Sapientiale, lib. I, c. 29, F, f. 35rb; Retucci, “Tommaso di York, Eustrazio e la dottrina delle idee di Platone”, p. 91, l. 66-p. 93, 1. 153 
v. Berthold of Moosburg, Expositio super Elementationem theologicam Procli. Prop. 108-135, ed. F. Retucci (Hamburg: Meiner, 2011).

1. Prop. 114A (p. 40, l. 10-p. 41, l. 39): cf. Sapientiale, lib. I, c. 10, F, f. 10va-b

2. Prop. $116 \mathrm{C}$ (p. 61, l. 69-p. 63, l. 128): cf. Sapientiale, lib. I, c. 5, F, ff. 5vb-6ra

3. Prop. 120 A (p. 9o, l. 11-20): cf. Sapientiale, lib. I, c. 5, F, f. 6ra-b

4. Prop. 120A (p. 9o, l. 21-p. 91, l. 42): cf. Sapientiale, lib. I, c. 6, F, f. 6rb

5. Prop. 120 A (p. 91, l. 43-5o): cf. Sapientiale, lib. I, c. 10, F, f. 1ova

6. Prop. 120 D (p. 93, l. 113-p. 97, l. 204): cf. Sapientiale, lib. I, cc. 35-36, F, ff. 4ova-42rb

7. Prop. 122A (p. 114, l. 13-p. 115, l. 52): cf. Sapientiale, lib. I, c. 7, F, f. 8ra-b

8. Prop. 131A (p. 19o, l. 10-p. 191, l. 44): cf. Sapientiale, lib. I, c. 6, F, ff. 6rb-vb

9. Prop. 131B (p. 191, l. 46-p. 194, l. 115): cf. Sapientiale, lib. I, c. 14, F, ff. 14ra-va

10. Prop. 132B (p. 200, l. 23-p. 201, l. 38): cf. Sapientiale, lib. viI, c. 10, F, f. 224va-b

11. Prop. 132D (p. 201, l. 50-53): cf. Sapientiale, lib. VII, c. 10, F, f. 224vb

12. Prop. $132 \mathrm{D}$ (p. 202, l. 56-62): cf. Sapientiale, lib. viI, c. 10, F, f. 224vb

13. Prop. 132D (p. 201, l. 5O-p. 202, l. 62). cf. Sapientiale, lib. VII, c. 10, F, f. 224vb

14. Prop. 133A (p. 206, l. 18-27): cf. Sapientiale, lib. VI, c. 2 (Città del Vaticano, Biblioteca Apostolica Vaticana, Vat. lat. 4301: lib. v, c. 2), F, ff. 184vb-185ra

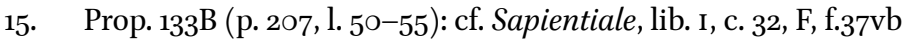

16. Prop. ${ }_{133 B}$ (p. 208, l. 66-82): cf. Sapientiale, lib. I, c. 32, F, ff. 37vb-38rb

17. Prop. 133D (p. 209, l. 112-113): cf. Sapientiale, lib. I, c. 16, F, f. 17vb

18. Prop. ${ }_{133}$ D (p. 210, l. 116-117), cf. Sapientiale, lib. I, c. 16, F, f. 17vb

19. Prop. $133 \mathrm{H}$ (p. 211, l. 166-174): cf. Sapientiale, lib. I, c. 32, F, f. 37vb

20. Prop. 135A (p. 220, l. 12-23): cf. Sapientiale, lib. VI, c. 2 (Città del Vaticano, Biblioteca Apostolica Vaticana, Vat. lat. 4301: lib. v, c. 2), F, ff. 184vb-185ra

21. Prop. 135A (p. 221, l. 33-p. 223, l. 8o): cf. Sapientiale, lib. vi, c. 2 (Città del Vaticano, Biblioteca Apostolica Vaticana, Vat. lat. 4301: lib. v, c. 2), F, f. $185 \mathrm{ra}-\mathrm{b}$

VI. Berthold of Moosburg, Expositio super Elementationem theologicam Procli. Propositiones 136-159, ed. F. Retucci (Hamburg: Meiner, 2007).

1. Prop. 136 A (p. 3, l. 13-p. 5, l. 56): cf. Sapientiale, lib. I, c. 18; Liber viginti quattuor philosophorum, p. 94, 1. 205-p. 96, 1. 261

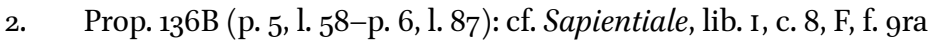

3. Prop. 136E (p. 6, l. 109-p. 7, l. 138): cf. Sapientiale, lib. III, c. 10 (Città del Vaticano, Biblioteca Apostolica Vaticana, Vat. lat. 4301: lib. IV, c. 10), F, f. 104rb

4. Prop. 136E (p. 8, l. 143-168): cf. Sapientiale, lib. III, c. 11 (Città del Vaticano, Biblioteca Apostolica Vaticana, Vat. lat. 4301: lib. IV, c. 11), F, ff. 104vb-105ra

5. Prop. 137E (p. 19, l. 145-p. 21, l. 201): cf. Sapientiale, lib. v, c. 11 (Città del Vaticano, Biblioteca Apostolica Vaticana, Vat. lat. 4301: lib. III, c. 11), F, f. 149va-b; Thomae Eboracensis Sapientiale. Liber III. Cap. 1-20, p. 143, 1. 65-p. 146, 1. 136 
6. Prop. ${ }_{137}$ E (p. 21, l. 202-205): cf. Sapientiale, lib. V, c. 11 (Città del Vaticano, Biblioteca Apostolica Vaticana, Vat. lat. 4301: lib. III, c. 11), F, f. 15orb; Thomae Eboracensis Sapientiale. Liber III. Cap. 1-20, p. 151, l. 26o-265

7. Prop. 137E (p. 21, l. 206-211); cf. Sapientiale, lib. V, c. 11 (Città del Vaticano, Biblioteca Apostolica Vaticana, Vat. lat. 4301: lib. III, c. 11), F, f. 150va; Thomae Eboracensis Sapientiale. Liber III. Cap. 1-20, p. 153, 1. 305-312

8. Prop. 142A (p. 52, l. 18-p. 54, l. 65): cf. Sapientiale, lib. I, c. 16, F, ff. 17ra-19rb; II, 30 (Città del Vaticano, Biblioteca Apostolica Vaticana, Vat. lat. 4301: lib. II, 29), F, f. $87 \mathrm{vb}$

9. Prop. ${ }_{143} \mathrm{~N}$ (p. 71, l. 401-p. 72, l. 426): cf. Sapientiale, lib. v, c. 26 (Città del Vaticano, Biblioteca Apostolica Vaticana, Vat. lat. 4301: lib. III, c. 26), F, f. 171ra

10. Prop. 146 D (p. 91, 1. 58-p. 92, l. 71): cf. Sapientiale, lib. VI, c. 5 (Città del Vaticano, Biblioteca Apostolica Vaticana, Vat. lat. 4301: lib. v, c. 5), F, f. 188rb

11. Prop. 146E (p. 92, l. 73-p. 93, l. 93): cf. Sapientiale, lib. VI, c. 5 (Città del Vaticano, Biblioteca Apostolica Vaticana, Vat. lat. 4301: lib. v, c. 5), F, f. 188rb

12. Prop. 146G (p. 93, l. 106-p. 94, l. 124): cf. Sapientiale, lib. I, c. 18; Liber viginti quattuor philosophorum, p. 9o, l. 73-p. 91, l. 107

13. Prop. 146H (p. 94, l. 144-p. 96, l. 182): cf. Sapientiale, lib. I, c. 17, F, f. 22 rb

14. Prop. 146I (p. 96, l. 198-p. 97, l. 209): cf. Sapientiale, lib. vI, c. 5 (Città del Vaticano, Biblioteca Apostolica Vaticana, Vat. lat. 4301: lib. v, c. 5), F, f. 188rb-va

15. Prop. 146L (p. 97, l. 232-p. 98, l. 249): cf. Sapientiale, lib. v, c. 21 (Città del Vaticano, Biblioteca Apostolica Vaticana, Vat. lat. 4301: lib. III, c. 21), F, f. 164ra-b

16. Prop. ${ }_{147}$ E (p. 103, l. 94-108): cf. Sapientiale, lib. II, c. 2, F, f. 51rb

17. Prop. 149D (p. 114, l. 91-p. 115, l. 130): cf. Sapientiale, lib. III, cc. 24-26 (Città del Vaticano, Biblioteca Apostolica Vaticana, Vat. lat. 4301: lib. IV, cc. 24-26), F, ff. 119ra-121rb

18. Prop. $15 \mathrm{oD}$ (p. 121, l. 70-p. 125, l. 193): cf. Sapientiale, lib. v, c. 8 (Città del Vaticano, Biblioteca Apostolica Vaticana, Vat. lat. 4301: lib. III, c. 8), F, ff. 145va-146ra; Thomae Eboracensis Sapientiale. Liber III. Cap. 1-20, p. 94, 1. 27-p. 95, l. 64

19. Prop. ${ }_{151}$ A (p. 134, l. 70-81): cf. Sapientiale, lib. I, c. 14, F, f. 14rb

20. Prop. ${ }_{151}$ D (p. 137, l.184-p. 138, l. 193); cf. Sapientiale, lib. v, c. 13 (Città del Vaticano, Biblioteca Apostolica Vaticana, Vat. lat. 4301: lib. III, c. 13), F, f. 151vb; Thomae Eboracensis Sapientiale. Liber III. Cap. 1-20, p. 167, 1. 28-p. 168, 1. $5^{1}$

21. Prop. 153A (p. 148, l. 12-p. 149, l. 40): cf. Sapientiale, lib. v, c. 26 (Città del Vaticano, Biblioteca Apostolica Vaticana, Vat. lat. 4301: lib. III, c. 26), F, f. 171ra

22. Prop. ${ }_{153}$ E (p. 153, l. 181-p. 154, l. 210): cf. Sapientiale, lib. v, c. 26 (Città del Vaticano, Biblioteca Apostolica Vaticana, Vat. lat. 4301: lib. III, c. 26), F, f. 171vb

23. Prop. ${ }_{157}$ D (p. 179, l. 67-79): cf. Sapientiale, lib. I, c. 16, F, ff. 19rb-2ova; lib. I, c. 17, F, f. $23 \mathrm{vb}$ 
24. Prop. 159A (p. 189, l. 14-p. 191, l. 73): cf. Sapientiale, lib. v, c. 21 (Città del Vaticano, Biblioteca Apostolica Vaticana, Vat. lat. 4301: lib. III, c. 21), F, ff. 164vb-165rb

25. Prop. 159B (p. 191, l. 75-p. 193, l. 137): cf. Sapientiale, lib. II, c. 11, F, ff. 68vb-69ra

26. Prop. 159D (p. 194, l. 177-p. 195, l. 182): cf. Sapientiale, lib. v, c. 29 (Città del Vaticano, Biblioteca Apostolica Vaticana, Vat. lat. 4301: lib. III, c. 29), F, f. 175ra

27. Prop. 159D (p. 196, l. 215-227): cf. Sapientiale, lib. II, c. 11, F, f. 69 ra

VII. Berthold of Moosburg, Expositio super Elementationem theologicam Procli. Propositiones 160-183, eds U.R. Jeck, I.J. Tautz (Hamburg: Meiner, 2003).

1. Prop. 16oG (p. 7, l. 126-137): cf. Sapientiale, lib. v, c. 26 (Città del Vaticano, Biblioteca Apostolica Vaticana, Vat. lat. 4301: lib. III, c. 26), F, f. 172ra

2. Prop. 162 D (p. 19, l. 95-p. 20, l. 135): cf. Sapientiale, lib. I, c. 15, F, ff. 15rb-va

3. Prop. ${ }_{164}$ D (p. 33, l. 66-71): cf. Sapientiale, lib. viI, c. 1, F, f. 212rb

4. Prop. ${ }_{164}$ D (p. 33, l. 81-87): cf. Sapientiale, lib. viI, c. 1, F, f. 212rb

5. $\quad$ Prop. 164E (p. 34, l. 101-p. 35, l. 131): cf. Sapientiale, lib. viI, c. 1, F, f. 212ra

6. Prop. ${ }_{165}$ D (p. 40, l. 79-p. 41, l. 107): cf. Sapientiale, lib. viI, c. 5, F, f.6ovb

7. Prop. 166B (p. 48, l. 70-p. 49, l. 99): cf. Sapientiale, lib. viI, c. 11, F, f. $227 \mathrm{rb}$

8. Prop. 166B (p. 49, l. 102-p. 5o, l. 124): cf. Sapientiale, lib. VII, c. 12, F, f. 227rb-va

9. Prop. $166 \mathrm{G}$ (p. 52, l. 206-p. 55, 1. 266): cf. Sapientiale, lib. viI, c. 12, F, f. 63vb-64va

10. Prop. $166 \mathrm{H}$ (p. 55, l. 267-276): cf. Sapientiale, lib. vII, c. 12, F, f. 64 va

11. Prop. 171 D (p. 114, l. 158-p. 115, l. 210): cf. Sapientiale, lib. vII, c. 17, F, ff. 220vb-221rb

12. Prop. $174 \mathrm{G}$ (p. 142, l. 197-205): cf. Sapientiale, lib. v, c. 13 (Città del Vaticano, Biblioteca Apostolica Vaticana, Vat. lat. 4301: lib. III, c. 13), F, ff. 152ra-vb; Thomae Eboracensis Sapientiale. Liber III. Cap. 1-20, p. 175, 1. 240-243; p. 166, 1. 9-19

13. Prop. 176A (p. 157, l. 15-p. 16o, l. 87): cf. Sapientiale, lib. I, c. 27, F, ff. 32va-33ra; Retucci, “Tommaso di York, Eustrazio e la dottrina delle idee di Platone", p. 91, l. $66-$ p. $93,1.153$

14. Prop. 176B (p.16o, l. 9o-93): cf. Sapientiale, lib. I, c. 27, F, f. 33ra; Retucci, “Tommaso di York, Eustrazio e la dottrina delle idee di Platone", p. 93, 1. 154-157

15. Prop. 176B (p. 16o, l. 102-p. 161, l. 120): cf. Sapientiale, lib. I, c. 27, F, f. 33ra; Retucci, “Tommaso di York, Eustrazio e la dottrina delle idee di Platone", p. 94, 1. 158-177

16. Prop. 176B (p. 161, l. 121-124): cf. Sapientiale, lib. I, c. 28, F, f. 33va; Retucci, “Tommaso di York, Eustrazio e la dottrina delle idee di Platone", p. 98, 1. 85-88

17. Prop. 176B (p. 161, l. 132-133): cf. Sapientiale, lib. I, c. 27, F, f. 33ra; Retucci, “Tommaso di York, Eustrazio e la dottrina delle idee di Platone”, p. 94, 1. 178-179

18. Prop. 176C (p. 161, l. 137-142): cf. Sapientiale, lib. I, c. 28, F, f. 33rb; Retucci, "Tommaso di York, Eustrazio e la dottrina delle idee di Platone", p. 96, l. 12-24

19. Prop. 176C (p. 162, l. 147-161): cf. Sapientiale, lib. I, c. 28, F, f. 33rb; Retucci, “Tommaso di York, Eustrazio e la dottrina delle idee di Platone", p. 96, l. 25-38

20. Prop. 176C (p. 162, l. 162-p. 163, l. 175): cf. Sapientiale, lib. I, c. 28, F, f. 33va; Retucci, “Tommaso di York, Eustrazio e la dottrina delle idee di Platone", p. 97, l. 48-64 
21. Prop. 176C (p. 163, l. 176-181): cf. Sapientiale, lib. I, c. 28, F, f. 33rb; Retucci, "Tommaso di York, Eustrazio e la dottrina delle idee di Platone", p. 98, 1. 72-8o

22. Prop. 176C (p. 164, l. 214-p. 165, l. 239): cf. Sapientiale, lib. I, c. 28, F, ff. 33va-b; Retucci, “Tommaso di York, Eustrazio e la dottrina delle idee di Platone", p. 98, l. $95^{-}$p. 99 , 1. 120

23. Prop. 176D (p. 165, l. 244-263): cf. Sapientiale, lib. I, c. 29, F, ff. 34rb-va; Retucci, “Tommaso di York, Eustrazio e la dottrina delle idee di Platone", p. 103, l.18-p. 104, 1. 37

24. Prop. 176 D (p. 165, l. 265-p. 166, l. 270): cf. Sapientiale, lib. I, c. 29, F, f. 34va; Retucci, "Tommaso di York, Eustrazio e la dottrina delle idee di Platone", p. 104, l. $5^{2-58}$

25. Prop. 176D (p. 166, l. 272-279): cf. Sapientiale, lib. I, c. 29, F, f. 34va; Retucci, “Tommaso di York, Eustrazio e la dottrina delle idee di Platone", p. 104, l. 62-p. 105, 1. 68

26. Prop. ${ }_{177}$ I (p. 183, l. 335-p. 184, l. 349): cf. Sapientiale, lib. I, c. 29, F, f. 35rb; Retucci, “Tommaso di York, Eustrazio e la dottrina delle idee di Platone", p. 109, l. 215-p.110, 1. 223

27. Prop. 178A (p. 188, l. 12-p. 19o, l. 54): cf. Sapientiale, lib. I, c. 29, F, f. 34va-b; Retucci, “Tommaso di York, Eustrazio e la dottrina delle idee di Platone", p. 105, l. 73-p. 106, l. 129

28. Prop. 178B (p. 19o, l. 56-p. 191, l. 111): cf. Sapientiale, lib. I, c. 29, F, f. 34vb; Retucci, “Tommaso di York, Eustrazio e la dottrina delle idee di Platone", p. 107, l. $130-$ p. $108,1.178$

29. Prop.178B (p. 192,l.114-120):cf. Sapientiale, lib. I, c. 29, F, f.35rb; Retucci, "Tommaso di York, Eustrazio e la dottrina delle idee di Platone", p. 108, l. 19o-p. 109, l. 196

30. Prop. 178B (p. 192, l. 137-139): cf. Sapientiale, lib. I, c. 29, F, f. 35rb; Retucci, “Tommaso di York, Eustrazio e la dottrina delle idee di Platone", p. 109, 1. 197-199

31. Prop. 178C (p. 193, l. 148-p. 194, l. 193): cf. Sapientiale, lib. I, c. 30, F, ff. 35vb-36ra

32. Prop. 178E (p. 196, l. 258-p. 197, l. 283): cf. Sapientiale, lib. I, c. 27, F, f. 33ra-b; Retucci, “Tommaso di York, Eustrazio e la dottrina delle idee di Platone", p. 95, 1. 184-204

33. Prop. 179A (p. 200, l. 12-27): cf. Sapientiale, lib. v, c. 1 (Città del Vaticano, Biblioteca Apostolica Vaticana, Vat. lat. 4301: lib. IV, c. 33), F, f. 128ra

34. Prop. 18oD (p. 213, l. 53-p. 214, l. 79): cf. Sapientiale, lib. VI, c. 19 (Città del Vaticano, Biblioteca Apostolica Vaticana, Vat. lat. 4301: lib. v, c. 19), F, f. 194ra-b

35. Prop. $18 \mathrm{oE} \mathrm{(p.} \mathrm{214,} \mathrm{l.} \mathrm{81-p.} \mathrm{216,} \mathrm{l.} \mathrm{122):} \mathrm{cf.} \mathrm{Sapientiale,} \mathrm{lib.} \mathrm{VI,} \mathrm{c.} 19$ (Città del Vaticano, Biblioteca Apostolica Vaticana, Vat. lat. 4301: lib. v, c. 19), F, ff. 194rb-vb

VIII. Berthold of Moosburg, Expositio super Elementationem theologicam Procli. Propositiones 184-211, ed. L. Sturlese (Hamburg: Meiner, 2014).

1. Prop. 184A (p. 3, l. 13-p. 5, l. 83): cf. Sapientiale, lib. VII, c. 15, F, ff. 212vb-213rb

2. Prop. 184 C (p. 6, l. 101-116): cf. Sapientiale, lib. viI, c. 16, F, f. 213va-b 
3. Prop. 186A (p. 3o, l. 11-p. 31, l. 44): cf. Sapientiale, lib. VII, c. 17, F, ff. 214vb-215rb

4. Prop. 186B (p. 31, l. 55-p. 32, l. 71): cf. Sapientiale, lib. VII, c. 18, F, ff. 215vb-216va

5. $\quad$ Prop. 186 D (p. 34, l. 153-p. 35, l. 178): cf. Sapientiale, lib. vII, c. 19, F, f. 217ra-vb

6. Prop. 187 A (p. 43, l. 37-p. 44, l. 68): cf. Sapientiale, lib. viI, c. 23, F, ff. 222rb-va

7. Prop. 187 A (p. 44, l. 81-83): cf. Sapientiale, lib. viI, c. 23, F, f. 222rb

8. Prop. 187 C (p. 47, l. 18o-p. 48, l. 212): cf. Sapientiale, lib. viI, c. 24, F, f. 223 ra

9. Prop. $19 \circ A$ (p. 76, l. 15-22): cf. Sapientiale, lib. VII, c. 18, F, f. 216 ra

10. Prop. 19oA (p. 77, l. 43-57): cf. Sapientiale, lib. VII, c. 18, F, f. 216 ra

11. Prop. 19oA (p. 79, l. 103-106): cf. Sapientiale, lib. vII, c. 18, F, f. 216ra-b

12. Prop. 19oA (p. 8o, l. 138-p. 81, l. 193): cf. Sapientiale, lib. VII, c. 18, F, ff. 216rb-va

13. Prop. 19oA (p. 82, l. 212-223): cf. Sapientiale, lib. VII, c. 18, F, f. 216va

14. Prop. $19 \circ B$ (p. 82, l. 215-217): cf. Sapientiale, lib. VII, c. 18, F, f. 216va

15. Prop. 199A (p. 151, l. 12-p. 153, l. 64): cf. Sapientiale, lib. VII, c. 1, F, f. 212ra-b

16. Prop. 199B (p. 153, l. 72-p. 155, l. 131): cf. Sapientiale, lib. viI, c. 6, F, f. 62ra-b

17. Prop. 199 C (p. 156, l. 158-178): cf. Sapientiale, lib. viI, c. 6, F, f. 61vb

18. Prop. 207 C (p. 227, l. 94-p. 228, l. 104): cf. Sapientiale, lib. I, c. 29, F, f. 35ra-b; Retucci, “Tommaso di York, Eustrazio e la dottrina delle idee di Platone”, p. 108, l. $179-190$

19. Prop. 208D (p. 235, l. 128-139): cf. Sapientiale, lib. vII, c. 24, F, f. 223 ra

\section{Bibliography}

\section{Manuscripts}

Thomas of York, Sapientiale, Firenze, Biblioteca Nazionale Centrale, Conv. Soppr. A.vi.437.

Thomas of York, Sapientiale, Vaticano (Città del), Biblioteca Apostolica Vaticana, Vat. lat. 4301.

Thomas of York, Sapientiale, Vaticano (Città del), Biblioteca Apostolica Vaticana, Vat. lat. 6771 .

\section{Primary Sources}

Alberich of Reims, Philosophia, ed. R.-A. Gauthier, in R.-A. Gauthier, "Notes sur Siger de Brabant. II. Siger en 1272-1275, Aubry de Reims et la scission des Normands," in Revue des Sciences philosophiques et théologiques 68/1(1984), p. 3-49.

Auctoritates Aristotelis, ed. J. Hamesse, Louvain / Paris, Publications universitaires / Béatrice-Nauwelaerts, 1974.

Berthold of Moosburg, Expositio super Elementationem theologicam Procli. Prologus. Propositiones 1-13, eds M.R. Pagnoni-Sturlese, L. Sturlese, Hamburg, Meiner, 1984. 
Berthold of Moosburg, Expositio super Elementationem theologicam Procli.Propositiones 14-34, eds L. Sturlese, M.R. Pagnoni-Sturlese, B. Mojsisch, Hamburg, Meiner, 1986.

Berthold of Moosburg, Expositio super Elementationem theologicam Procli.Propositiones 35-65, ed. A. Sannino, Hamburg, Meiner, 2001.

Berthold of Moosburg, Expositio super Elementationem theologicam Procli.Propositiones 66-107, ed. I. Zavattero, Hamburg, Meiner, 2003.

Berthold of Moosburg, Expositio super Elementationem theologicam Procli. Prop. 108135, ed. F. Retucci, Hamburg, Meiner, 2011.

Berthold of Moosburg, Expositio super Elementationem theologicam Procli. Prop. 136159, ed. F. Retucci, Hamburg, Meiner, 2007.

Berthold of Moosburg, Expositio super Elementationem theologicam Procli. Prop. 160183, eds U.R. Jeck, I.J. Tautz, Hamburg, Meiner, 2003.

Berthold of Moosburg, Expositio super Elementationem theologicam Procli.Propositiones 184-211, ed. L. Sturlese, unter Mitarbeit von A. Punzi, Hamburg, Meiner, 2014.

Henry Bate, Speculum divinorum et quorundam naturalium. Parts VI-VII: On the Unity of Intellect. On the Platonic doctrine of the ideas, ed. C. Steel, E. Van der Vyver, Leuven, Leuven University Press, 1994.

Liber viginti quattuor philosophorum, ed. F. Hudry, Turnhout, Brepols, 1997.

Thomas of York, Sapientiale. Liber III. Cap. 1-20, ed. A. Punzi, Firenze, SISM EL-Edizioni del Galluzzo, 2020.

\section{Secondary Sources}

Aersten, J.A., Medieval Philosophy as Transcendental Thought. From Philip the Chancellor (ca. 1225) to Francisco Súarez, Leiden, Brill, 2012.

Anzulewicz, H., "Albertus Magnus und seine Schüler. Versuch einer Verhältnisbestimmung," in A. Speer, Th. Jeschke (eds), Schüler und Meister, Berlin/Boston, De Gruyter, 2016, p. 159-203.

Benakis, L., "The Problem of General Concepts in Neoplatonism and Byzantine Thought," in D.J. O'Meara (ed.), Neoplatonism and Christian Thought, Albany, State University of New York Press, 1982, p. $75^{-86 .}$

Bianchi, L. "Filosofi, uomini e bruti. Note per la storia di un'antropologia 'averroista'," in Studi sull'Aristotelismo del Rinascimento, Padova, Il Poligrafo, 2003, p. 41-61.

Bonafede, G., Il pensiero francescano nel secolo XIII, Palermo, Mori e Figli, $195^{2}$.

Draelants, I., "La transmission du De animalibus d'Aristote dans le De floribus rerum naturalium d'Arnoldus Saxo," in C. Steel, G. Guldentops, P. Beullens (eds), Aristotle's Animals in the Middle Ages and Renaissance, Leuven, Leuven University Press, 1999, p. $126-158$.

Gersh, “Universals, Wholes, Logoi: Eustratios of Nicaea's Response to Proclus' Elements of Theology," in D. Calma (ed.), Reading Proclus and the Book of Causes. Volume 2, Leiden, Brill, 202O, p. 40-55. 
Giocarinis, K., "Eustratios of Nicea's Defense of the Doctrine of the Ideas," in Franciscan Studies 24(1964), p. 159-204.

Grabmann, M., "Die Metaphysik des Thomas von York," in Studien zur Geschichte der Philosophie. Festgabe zum 6o. Geburtstag Clemens Baeumker, Münster i.W., Aschendorff, 1913, p. 181-193.

Grabmann, M., "Der Einfluss Alberts des Grossen auf das mittelalterliche Geistesleben," in Mittelalterliches Geistesleben, vol. 2, München, Max Hueber Verlag, 1936, p. $325-412$.

Grignaschi, M., "Indagine sui passi del «Commento » suscettibili di aver promosso la formazione di un averroismo politico," in L'averroismo in Italia, Roma, Accademia Nazionale dei Lincei, 1979, p. 237-288.

Guldentops, G., "Henry Bate's Aristocratic Eudaemonism," in J.A. Aertsen, K. Emery, A. Speer (eds), Nach der Verurteilung von 1277. Philosophie und Theologie an der Universität von Paris im letzten Viertel des 13. Jahrhunderts: Studien und Texte, Berlin, De Gruyter, 2001, p. 657-681.

Ierodiakonou, K., "Metaphysics in the Byzantine Tradition. Eustratios of Nicea on Universals," in Quaestio 5(2005), p. 67-82.

Kaeppeli, Th., "Ein Fragment der Akten des in Friesach 1315 gefeierten Kapitels des Provinz Teutonia," in Archivum Fratrum Praedicatorum 48(1978), p. 71-75.

Krzanic, C., "Grandi lottatori contro l'Averroismo," in Rivista di filosofia neoscolastica 22(1930), p. 161-207.

Largier, N., "Die deutsche Dominikanerschule. Zur Problematik eines historiographiscen Konzepts," in J.A. Aertsen, A. Speer (eds), Geistesleben im 13. Jahrhundert, Berlin / New York, De Gruyter, 200o, p. 202-213.

Libera, A. de, "Théorie des universaux et réalisme logique chez Albert le Grand," in Revues des Sciences Philosophiques et Théologiques 65(1981), p. 55-74.

Libera, A. de, "Albert le Grand et le Platonisme. De la doctrines des Idées à la théorie des trois états de l'Universel," in E.P. Bos, P.A. Meijer (eds), On Proclus and his Influence in Medieval Philosophy, Leiden / New York / Köln, Brill, 1992, p. 89-119.

Libera, A. de, Métaphysique et noétique. Albert le Grand, Paris, Vrin, 2005.

Löhr, G.M., Die Kölner Dominikanerschule vom 14 bis zum 16. Jarhundert, Freiburg, Verl. der Paulusdr., 1946.

Longpré, E., "Fr. Thomas d'York, O.F.M. La première somme métaphysique du XIII e siècle," in Archivum Franciscanum Historicum 19(1926), p. 875-930.

Mojsisch, B., "Aristoteles' Kritik an Platons Theorie der Ideen und die Dietrich von Freiberg berücksichtigende Kritik dieser Kritik seitens Bertholds von Moosburg," in K.-H. Kandler, B. Mojsisch, F.B. Stammkötter (eds), Dietrich von Freiberg. Neue Perspektiven seiner Philosophie, Theologie und Naturwissenschaft, Amsterdam / Philadelphia, Grüner, 1999, p. 267-281.

Palazzo, A., "La ricezione di un passo ermetico (Asclepius 8) nel tardo medioevo. Ulrico di Strasburgo, Pietro di Tarantasia, Riccardo di Mediavilla, Bertoldo di Moosburg e 
Dionigi il Certosino," in T. Iremadze, T. Tskhadadze, G. Kheoshvili (eds), Philosophy, Theology, Culture. Problems and Perspectives. Jubilee Volume Dedicated to the 75th Anniversary of Guram Tevzadze, Tbilisi, Nekeri-Arche, 2007, p. 104-125.

Retucci, F., "Magister Thomas Anglicus Minor. Eine neue Quelle der Expositio super Elementationem theologicam Procli Bertholds von Moosburg - das ungedruckte Sapientiale des Franziskaners Thomas von York," in Berthold of Moosburg, Expositio super Elementationem theologicam Procli. Prop. 136-159, ed. F. Retucci, Hamburg, Meiner, 2007, p. XXIII-XXXIX.

Retucci, F., "Tommaso di York, Eustrazio e la dottrina delle idee di Platone," in A. Beccarisi, P. Porro, R. Imbach (eds), Per perscrutationem philosophicam. Neue Perspektiven der mittelalterlichen Forschung. Loris Sturlese zum 6o. Geburtstag gewidmet, Hamburg, Meiner, 2008, p. 79-110.

Retucci, F., "Magister Thomas Anglicus Minor. Tommaso di York fonte dell'Expositio di Bertoldo di Moosburg," in Tra antichità e modernità. Studi di storia della filosofia medievale e rinascimentale, Quaderni di Noctua 5(2019), p. 1-41.

Retucci, F., "The De causis in Thomas of York," in D. Calma (ed.), Reading Proclus and the Book of Causes. Volume 1, Leiden, Brill, 2019, p. 70-119.

Schmieja, H., "Drei Prologen im grossen Physikkommentar des Averroes," in A. Zimmermann (ed.), Aristotelisches Erbe im arabisch-lateinischen Mittelalter, Berlin / New York, De Gruyter, 1986, p. 175-189.

Scully, E., "Thomas of York and his Use of Aristotle. An Early Moment in the History of British Philosophy," in Culture 20(1959), p. 420-436.

Sharp, D.E., Franciscan Philosophy at Oxford, New York, Russell, 1964.

Smalley, B., English Friars and Antiquity in the early Fourteenth Century, Oxford, Blackwell, 196 o.

Steel, C., "Neoplatonic Sources in the Commentaries on the Nicomachean Ethics by Eustratius and Michael of Ephesus," in Bulletin de Philosophie Médiévale 44(2002), p. $5^{1-57}$.

Sturlese, L., "Albert der Grosse und die deutsche philosophische Kultur des Mittelalters," in Freiburger Zeitschrift für Philosophie und Theologie 28(1981), p. 133-147.

Sturlese, L., Die deutsche Philosophie im Mittelalter. Von Bonifatius bis zu Albert dem Großen (784-1280), München, Beck, 1993.

Sturlese, L., Homo divinus. Philosophische Projekte in Deutschland zwischen Meister Eckhart und Heinrich Seuse, Stuttgart, Kohlhammer, 2007.

Trizio, M., "Dissensio philosophorum. Il disaccordo tra Platone e Aristotele nei commenti filosofici di Eustrazio di Nicea († ca. 1120)," in A. Palazzo (ed.), L'antichità classica nel pensiero medievale, Porto, Fédérations Internationale des Instituts d'Études Médiévales, 2011, p. 17-37.

Zavattero, I., "Proclus, Eustrate de Nicée et leur réception aux XIII ${ }^{\mathrm{e}}-\mathrm{XIV}{ }^{\mathrm{e}}$ siècles," in D. Calma (ed.), Reading Proclus and the Book of Causes. Volume 1, Leiden, Brill, 2019, p. $327-351$. 